\title{
Development of a Frit 202 Analytic Standard for the Defense Waste Processing Facility
}

by

R. F. Schumacher

Westinghouse Savannah River Company

Savannah River Site

Aiken, South Carolina 29808

B. J. Hardv

J. F. Sproull

\section{RECEIVED \\ JUL 211997 \\ O.STI}

This paper was prepared in connection with work done under the above contract number with the U.S. Department of Energy. By acceptance of this paper, the publisher and/or recipient acknowledges the U.S. Government's right to retain a nonexclusive, royalty-free license in and to any copyright covering this paper, along with the right to reproduce and to authorize others to reproduce all or part of the copyrighted paper. 


\section{DISCLAMMER}

Portions of this docoment mey be illegible in electronic image products. Images are produced from the best available origion docomentert 
Westinghouse Savannah River Company

WSRC-TR-96-0414

Revision 0

To: David A. Crowley, 773-43A

Distribution:

L.M. Papouchado, 773-A

E.W. Holtzscheiter, 773-A

E.F. Duhn, 773-A

N.E. Bibler, 773-A

L.R. Landon, 704-T

C.T. Randall, 704-T

J.R. Harbour, 773-43A

K.G. Brown, 704-T

J.F. Sproull, 704-35S

P.F. Cloessner, 773-A

C.J. Coleman, 773-A

A.R. Jurgensen, 773-A

H.J. Kunis, 704-15S

S.R. Loflin, 773-41A

B.J. Hardy, 704-T

GF\&MT

$\mathrm{DC} / \mathrm{RM}(4), 773-53 \mathrm{~A}$ 
WSRC-TR-96-0414, Rev. 0

Distribution Category: UC-721

Keywords: Frit, Analyses

DWPF, Standards

Retention Time: Permanent

March 30.1997

\section{DEVELOPMENT OF A FRIT 202 ANALYTIC \\ STANDARD FOR THE DEFENSE WASTE \\ PROCESSING FACILITY - (U)}

R.F. SCHUMACHER, B.J. HARDY \& J.F. SPROULL

Westinghouse Savannah River Co.

Savannah River Site

Aiken, SC 29808

Prepared for the U.S. Department of Energy Under contract DE-AC09-89SR18035 
This page intentionally left blank. 
Approvals \& Technical Review

WSRC-TR-96-0414

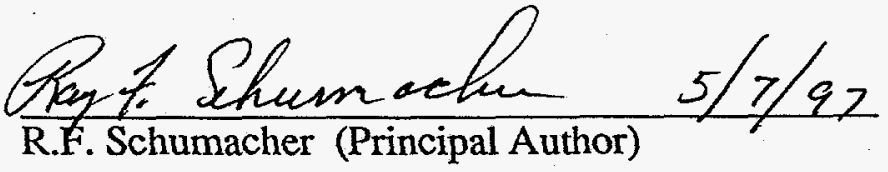

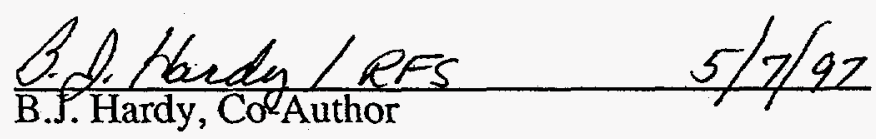

$\frac{\text { d.F Sproull / RFs }}{\text { James F. Sproull, Co-Author }} 5 / 7 / 97$

Gilm R tanlour

$5 / 7 / 97$

Jofn R. Harbour, Technical Review

Cavid A. Comly 5/8/97

Mgr. Glass Formulation \& Melter Technology

UW foetzatict $6 / 4(9)$

E.W. Holtzscheiter,

Mgr. Vitrification Technology Section

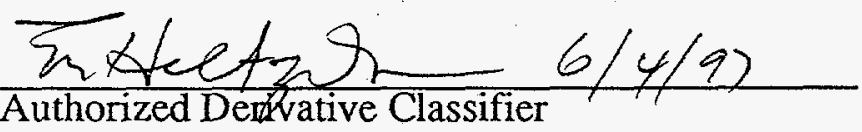

$-3-$ 
This page intentionally left blank. 


\begin{abstract}
During the qualification of Frit 202 samples for the "DWPF Cold Runs", the need for a reliable chemical frit standard became apparent. A standard was prepared by obtaining a quantity of Frit 202 and grinding into a fine powder. This material was homogenized as one slurry material volume, spray dried to prevent segregation, and hydraulically pressed into discs. These discs were fired and packaged into eleven sub-lots containing approximately 2,000 discs per sub-lot. A number of samples were obtained and analyzed by two analytic laboratories. The chemical analyses were carefully reviewed and evaluated by several statistical means. While there were several statistically significant variations between the sub-lots, it is believed that these variations are partially caused by the variability of the analytic method. These discs should provide a reliable standard for future chemical analyses of DWPF Frits similar in composition to Frit 202.

It is recommended that these discs be used as a standard material included with the representative frit sample to the independent chemical analysis laboratory, and the order of use of these standards be from sub-lot eleven to sub-lot four. It is further recommended that the NIST standard material (93a) be employed along with the 202 standard until confidence in the new standard is gained. The NIST standard should also be used when initial use of a new sub-lot is begun. This procedure should continue to the end of the DWPF program or such time as the chemical composition of the frit is extensively modified.
\end{abstract}


This page intentionally left blank. 
TABLE OF CONTENTS

SECTIONS

Page No.

Approvals \& Technical Review

3

Abstract

5

Introduction

Summary

9

Experimental

9

Obtaining Glass Frit

Preparation of Glass Discs

9

Samples and Analyses

11

12

Discussion of Results

14

Acknowledgments

16

References

16

Appendix A

CELS Analysis Frit 202 - Lot 6

17

Appendix B

Ferro Report - Disc Manufacture and

$18-34$

Spectrochemical Analyses

Appendix C CELS Analysis Report - Fired Discs -

$35-37$

Lots 3, 5, 7, 9, and 11 .

Appendix D Statistical Analysis of Ferro Data

$38-48$

Distribution (JMP) - Bruce Hardy

\section{TABLES}

Table 1 Chemical Analyses (CELS) Frit 202 - Lot 6 and NIST 93a Standard

Table 2 Samples Taken During and After Disc Manufacture

Table 3 Summary of Chemical Analyses from SLI and CELS Sub-Lots 1 to 11

Table 4 CELS Analyses of Fired Discs from

Sub-Lots 3,5,7,9, and 11

Table 5 Comparison of Average and Standard Deviations

for Sub-Lot samples, Powder Samples and

Continuous Samples 
This page intentionally left blank. 


\section{DEVELOPMENT OF A FRIT 202 ANALYTIC STANDARD FOR THE DEFENSE WASTE PROCESSING FACILITY - (U)}

\section{INTRODUCTION}

During the chemical evaluation of initial samples of DWPF Frit 202 for the "Cold Runs", it became apparent, that the establishment of a glass "standard" similar to Frit 202 would be an advantage to the DWPF program[1]. During these evaluations, a National Institute of Standards and Technology (NIST) standard borosilicate glass, NIST No. 93a, was employed to validate the chemical analyses of the DWPF frits. The major disadvantage of using NIST No. 93a as a standard is that it has only three of the five primary components of the DWPF frits and the proportions are significantly different from the composition of the DWPF Frit. After discussion with the DWPF technical staff, it was decided to attempt to develop a glass standard similar in composition to DWPF Frit 202.

An acceptable chemical analysis standard should meet the following general criteria: 1) the standard should have a chemical composition similar to the material to be analyzed, 2) the standard should have a similar physical matrix e.g. a glass, ceramic, metal, etc., 3) the standard should be stable with time, and 4) all the pieces in the standard should be of convenient size and essentially identical chemically. Meeting these requirements and proving that the requirements have been met, beyond a reasonable doubt, provides a rather daunting task.

\section{SUMMARY}

A small lot of DWPF Frit 202 was obtained from the frit vendor, carefully ground into a fine powder, slurried in one mixer, and spray dried into a spherical feed for pressing into small discs. The discs were then fired on a carefully controlled, continuous belt furnace. As the discs exited the furnace they were sampled and partitioned into eleven sub-lots (ca. 2000 discs/ sub-lot). After extensive chemical analyses by two different chemical laboratories and inspection of the resulting data it was concluded the material produced could be employed as a chemical reference standard. It is suggested that the order of use be from sub-lot 11 to sub-lot 4 . The first three sub-lots $(1,2$, and 3$)$ are somewhat suspect and they should not be used. It is recommended that the NIST standard material (93a) should be included with the Frit 202 standard until confidence is gained in the new standard. The NIST standard should also be included when new sub-lot standards are employed, i.e. changing from sub-lot 11 to 10. Any person interested in obtaining samples of this analytic standard should contact Ray Schumacher, who will control the dispersion of samples.

\section{EXPERIMENTAL}

\section{Obtaining Glass Frit}

During the latter part of 1993 (September) approximately 850 pounds of Frit 202 were obtained from the DWPF frit vendor, Cataphote, Inc., (Jackson, MS). This material was left over after supplying the sixth lot of Frit 202 for the "Cold Runs". 
The material was obtained from Cataphote in two 51 gallon metal topped fiber drums with lid and ring clamp seals. The drums contained a polyethylene drum liner with four pre-packaged desiccant packs per drum. The drums were shrink wrapped to a wooden pallet and shipped to SRS. This was conducted under Purchase Requisition D-96950 (PO\#AA84373H).

While the material was not a part of Lot 6 , it was melted during the same campaign and with the same quality assurance controls. Lot 6 (September 1993) of Frit 202 was analyzed by Corning Engineering Laboratory Services (CELS) under LIMS\#12354. The analysis was verified with a National Institute of Standards Reference (NIST) Material 93a analyzed under the LIMS\#12355. The results of these analyses are presented in Table 1. Review of Table 1, shows that the normalized analyzed composition of this material is extraordinarily close to the DWPF target specification (within $0.02 \mathrm{wt} \%$ ). The analysis of the standard reference material NIST 93a is also very close to the NIST certified analysis (within $0.2 \mathrm{wt} \% \mathrm{SiO}_{2}$ ). In addition, inspection of this Table confirms the need for a better reference material for Frit 202. The general composition of the NIST material is somewhat different from Frit 202 and it does not contain lithia or magnesia. The official independent analysis for Lot 6 is presented at the end of this report in Appendix A. While it was a requirement of the purchase order that the composition of the supplied frit material meet the DWPF Frit 202 specification, it was serendipity that the normalized composition came as close to the target composition as it did ( $\pm 0.02 \mathrm{wt} \%)$.

Table 1

Chemical Analyses (CELS) Frit 202-Lot 6 and NIST 93a Standard

\begin{tabular}{|c|c|c|c|c|c|}
\hline Majors & $\begin{array}{l}\text { DWPF } \\
\text { Specification } \\
\left(\mathrm{Wt}_{\mathrm{t}}\right)\end{array}$ & $\begin{array}{l}\text { Lot } 6 \\
\text { CELS } \\
\# 12354 \\
\end{array}$ & $\begin{array}{l}\text { Lot } 6 \\
\text { Norm.to } \\
98.8 \\
\end{array}$ & $\begin{array}{l}\text { NIST 93a } \\
\text { Standard } \\
\text { (Wt\%) }\end{array}$ & $\begin{array}{l}\text { NIST 93a } \\
\text { CELS } \\
\# 12355 \\
\end{array}$ \\
\hline $\mathrm{SiO}_{2}$ & $77.0 \pm 1.0$ & 76.1 & 77.02 & 80.8 & 80.6 \\
\hline $\mathrm{Na}_{2} \mathrm{O}$ & $6.0 \pm 0.5$ & 5.92 & 5.99 & 3.98 & 3.97 \\
\hline $\mathrm{Li} 2 \mathrm{O}$ & $7.0 \pm 0.5$ & 6.90 & 6.98 & & \\
\hline $\mathrm{MgO}$ & $2.0 \pm 0.25$ & 1.98 & 2.00 & 0.005 & \\
\hline $\mathrm{B}_{2} \mathrm{O}_{3}$ & $8.0 \pm 0.5$ & 7.90 & 8.00 & 12.56 & 12.6 \\
\hline $\begin{array}{l}\text { Total } \\
\text { Minors }\end{array}$ & 100.0 & 98.8 & 100.00 & & \\
\hline $\mathrm{Al}_{2} \mathrm{O}_{3}$ & $<1.89$ & 0.34 & & 2.28 & 2.27 \\
\hline $\mathrm{Fe}_{2} \mathrm{O}_{3}$ & $<0.29$ & 0.038 & & 0.028 & \\
\hline $\mathrm{MnO}$ & $<0.32$ & $<.001$ & & & \\
\hline $\mathrm{NiO}$ & $<0.25$ & $<.001$ & & & \\
\hline $\mathrm{Cr}_{2} \mathrm{O}_{3}$ & $<0.15$ & $<.001$ & & & \\
\hline $\mathrm{PbO}$ & $<0.11$ & $<.001$ & & & \\
\hline $\mathrm{TiO}_{2}$ & $<0.25$ & 0.012 & & 0.014 & \\
\hline $\mathrm{F}$ & $<0.05$ & 0.007 & & & \\
\hline $\mathrm{Cl}$ & $<0.05$ & 0.014 & & 0.060 & \\
\hline Others & $<0.05$ & & & 0.042 & \\
\hline $\mathrm{K}_{2} \mathrm{O}$ & & & & 0.014 & \\
\hline $\mathrm{CaO}$ & & 0.04 & & 0.01 & \\
\hline $\mathrm{BaO}$ & & 0.067 & & & \\
\hline Total O & & 99.33 & & 99.77 & 99.44 \\
\hline LOD@ & $C<0.1$ & 0.06 & & & \\
\hline LOI@ & $C<0.1$ & 0.22 & & & \\
\hline
\end{tabular}


The two drums containing the 850 pounds of DWPF Frit 202 were received at SRS prior to being shipped to Ferro Corporation, Cleveland, Ohio for additional processing and fabrication of the discs.

\section{Preparation of Glass Discs}

In order to prepare a chemical glass standard, it is necessary to take into consideration several factors. First, the material should be mixed into a single homogeneous lot of material in a manner where any sample obtained for chemical analysis should have the same chemical composition. Second, the standard should have a structural matrix similar to the unknown. Third, the material should be stable such that it is not affected by its environment, e.g. humidity or time. Finally the standard should be of a convenient size and all pieces essentially identical on a chemical basis. Two bids were received to carry out this effort and prepare the reference standard. The first involved further grinding the frit into a homogeneous lot and pressing and firing the material into small discs. The other bid was to re-mix the frit powder, re-melt the powder in small lots and cast into shapes. It was felt that while the two approaches were quite different either process would probably have produced homogeneous standard samples. Procurement selected the initial process involving the manufacture of discs.

A Purchase Requisition (E13352) was prepared and a Purchase Order (AA84377A) was provided to Ferro Corporation to homogenize and fabricate a minimum of $250 \mathrm{lbs}$. of sintered glass discs.

The $850 \mathrm{lbs}$. of Frit 202 was received by the Electronic and Specialty Glass Department at Ferro Corporation and ground in four millings to an average $73 \%$ minus 325 mesh powder $(-325 \mathrm{M}=79.5 \%, 70.3 \%, 79.4 \%$, and $63.3 \%)$. A portion of the 850 pounds was used to initially "clean" the grinding mill and was discarded. The remaining material was ground in four millings in a 52 - gallon high-alumina mill with $75 \mathrm{~kg}$ of the Frit 202 in each milling. The grinding media was $204 \mathrm{kgs}$ of $13 / 16$ inch high alumina balls. Approximately $75 \mathrm{ml}$ of alcohol was added as a milling aid and milling time was 7 to 8 hours. The product was designated F-202 PRF while at Ferro Corp. The four millings, $(300 \mathrm{kgs})$, were blended by hand prior to shipment to Elan Technology, a Division of Mansol Industries, Inc., for the additional processing.

Upon arrival at Elan Technology, the entire $300 \mathrm{kgs}$ of milled material was slurried in one large mixer to promote homogeneity of all the glass. The homogeneous slurry was then spray dried into small spherules with a 24 - foot spray dryer in about 25 minutes. An organic binder was added at a $4 \%$ level to hold the powder together before and after pressing and to prevent any type of particle segregation.

The spray dried powder was pressed into discs 1.13 inch in diameter and the run broken into 11 sub-lots. Pressing of the discs was accomplished with a ten - ton Denison Press. The firing of the discs was also completed at Elan Technology. The discs were fired on ceramic plates to a fired diameter of approximately one inch and a weight of approximately 6 grams. The belt speed in the furnace was 10 inches per minute and the maximum temperature was $1290^{\circ} \mathrm{F},\left(699^{\circ} \mathrm{C}\right)$. The furnace was divided into eight zones ranging in temperature from 450 to $1290^{\circ} \mathrm{F}$. The 11 sub-lots were fired in order and a total of approximately 20,850 discs were prepared by these procedures. 
Table 3

Summary of Chemical Analyses from SLI and CELS

Sub Lots 1 to 11

\begin{tabular}{rrrrrrr}
$\begin{array}{r}\text { Oxide } \\
\text { Sub-lot }\end{array}$ & MgO & Li2O & B2O3 & Na2O & SiO2 & Total \\
NSL-1 & wt\% & wt\% & wt\% & wt\% & wt\% & wt\% \\
2 & 2.02 & 6.90 & 7.65 & 5.59 & 77.24 & 99.40 \\
3 & 2.02 & 6.95 & 7.67 & 5.67 & 77.08 & 99.39 \\
4 & 2.03 & 7.07 & 7.61 & 5.73 & 76.96 & 99.40 \\
5 & 2.00 & 7.07 & 7.66 & 5.71 & 76.96 & 99.40 \\
6 & 2.01 & 7.00 & 7.67 & 5.74 & 77.00 & 99.43 \\
7 & 1.98 & 7.01 & 7.60 & 5.68 & 77.18 & 99.44 \\
8 & 1.99 & 7.01 & 7.61 & 5.70 & 77.12 & 99.43 \\
9 & 1.99 & 7.01 & 7.66 & 5.76 & 77.02 & 99.43 \\
10 & 2.01 & 7.04 & 7.67 & 5.71 & 77.01 & 99.44 \\
11 & 1.99 & 7.00 & 7.71 & 5.67 & 77.07 & 99.44 \\
\hline AVG & 2.00 & 6.99 & 7.65 & 5.68 & 77.12 & 99.45 \\
\hline Continuous & 2.00 & 7.00 & 7.65 & 5.70 & 77.07 & 99.42 \\
Powder & 1.99 & 6.99 & 7.67 & 5.68 & 77.11 & 99.43 \\
\hline CELS-3 & 2.01 & 7.00 & 7.66 & 5.69 & 77.16 & 99.52 \\
-5 & 1.94 & 6.94 & 7.81 & 5.98 & 76.1 & 99.37 \\
-7 & 1.98 & 6.97 & 7.77 & 5.96 & 76.3 & 99.60 \\
-9 & 1.94 & 6.91 & 7.71 & 5.96 & 75.9 & 99.02 \\
-11 & 1.96 & 6.97 & 7.73 & 5.97 & 76.3 & 99.59 \\
Avg. & 1.95 & 6.94 & 7.73 & 5.97 & 77.0 & 100.21 \\
High Value & 1.95 & 6.95 & 7.75 & 5.97 & 76.32 & 99.56 \\
Low Value & 2.03 & 7.07 & 7.81 & 5.98 & 77.24 & 100.21 \\
Range/Low & 1.94 & 6.90 & 7.60 & 5.59 & 75.90 & 99.02 \\
& $4.64 \%$ & $2.46 \%$ & $2.76 \%$ & $6.98 \%$ & $1.77 \%$ & $1.20 \%$
\end{tabular}


Table 4

Notebook No.E57157-46

CELS No. 15052-94-2

Sub-lot No.

Qxide Deter.

$\mathrm{Cr} 2 \mathrm{O} 3$

$\mathrm{NiO}$

$\mathrm{PbO}$

$\mathrm{K} 2 \mathrm{O}$

$\mathrm{Li} 2 \mathrm{O}$

$\mathrm{Na} 2 \mathrm{O}$

$\mathrm{Al} 2 \mathrm{O} 3$

$\mathrm{B} 2 \mathrm{O} 3$

$\mathrm{CaO}$

$\mathrm{Fe} 2 \mathrm{O} 3$

$\mathrm{MgO}$

$\mathrm{MnO} 2$

$\mathrm{SiO} 2$

$\mathrm{TiO} 2$

$\mathrm{F}$

$\mathrm{Cl}$

Total

Majors

Sub-Total

$\mathrm{Li} 2 \mathrm{O}$

$\mathrm{Na} 2 \mathrm{O}$

$\mathrm{B} 2 \mathrm{O} 3$

$\mathrm{MgO}$

$\mathrm{SiO} 2$

Total

CELS Analyses of Fired Discs from Sub-Lots 3,5,7,9, and 11

3

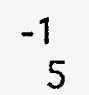

$$
<.001
$$

$<.001$

$<.001$

0.05

6.94

5.98

0.44

7.81

0.041

0.031

1.94

$<.001$

76.1

0.011

0.008

0.017

99.368

98.77

Normalized
$7.03 \%$

Data

$6.05 \%$

$7.91 \%$

$1.96 \%$

$7.04 \%$

$7.02 \%$

$6.06 \%$

$7.83 \%$

$7.85 \%$

$1.97 \%$
$77.12 \%$

$2.00 \%$

$77.05 \%$

$77.09 \%$

$100.00 \% \quad 100.00 \%$

$100.00 \%$

-5
9

$-4$

11 Avg

Std. Dev.

\section{DISCUSSION OF RESULTS}

Inspection of the data indicates that the Spectrochemical Lab analyses of the 78 fired disc samples are very similar and the comparison to the unfired powder is usually within one standard deviation. This was interpreted to mean that the firing process did not have a noticeable influence on the composition of the discs. This would be expected at the low firing temperature of $1290^{\circ} \mathrm{F}\left(699^{\circ} \mathrm{C}\right)$. Comparing the discs obtained from each sub-lot to the discs obtained consecutively, indicated that the standard deviation of the consecutive samples was approximately one half the values for the discs from the sub-lots. Assuming that the consecutive discs had essentially the same composition, then approximately half of the standard deviation observed was due to the variability of the chemical analyses. See Table 5. While the variability of the sub lot data is slightly greater than the samples obtained consecutively, the data is very consistent. There appears to be no significant difference in the analyses of the sub-lots compared to the consecutivley gathered samples. 
Table 5

Comparison of Average and Standard Deviations for Sub Lot

Samples, Powder Samples, and Consecutive Samples

\begin{tabular}{|c|c|c|c|c|c|c|c|}
\hline Sub Lot No & & $\begin{array}{r}\mathrm{MgO} \\
\mathrm{Wt} \%\end{array}$ & $\begin{array}{l}\mathrm{Li} 20 \\
\text { Wt\% }\end{array}$ & $\begin{array}{c}\mathrm{B} 203 \\
\mathrm{Wt} \%\end{array}$ & $\begin{array}{l}\mathrm{Na} 20 \\
\text { Wt\% }\end{array}$ & $\begin{array}{l}\mathrm{SiO} 2 \\
\mathrm{Wt} \%\end{array}$ & $\begin{array}{l}\text { Total } \\
\text { Wt\% }\end{array}$ \\
\hline \multirow[t]{2}{*}{$\# 1$} & Avg. & 2.02 & 6.90 & 7.65 & 5.59 & 77.24 & $\overline{99.40}$ \\
\hline & S.D. & 0.03 & 0.07 & 0.08 & 0.07 & 0.21 & \\
\hline \multirow[t]{2}{*}{ \#2 } & Avg. & 2.02 & 6.95 & 7.67 & 5.67 & 77.08 & 99.39 \\
\hline & S.D. & 0.03 & 0.07 & 0.08 & 0.06 & 0.14 & \\
\hline \multirow[t]{2}{*}{ \#3 } & Avg. & 2.03 & 7.07 & 7.61 & 5.73 & 76.96 & 99.40 \\
\hline & S.D. & 0.06 & 0.07 & 0.05 & 0.13 & 0.22 & \\
\hline \multirow[t]{2}{*}{$\# 4$} & Avg. & 2.00 & 7.07 & 7.66 & 5.71 & 76.96 & 99.40 \\
\hline & S.D. & 0.02 & 0.05 & 0.08 & 0.05 & 0.11 & \\
\hline \multirow[t]{2}{*}{$\# 5$} & Avg. & 1.98 & 7.01 & 7.60 & 5.68 & 77.18 & 99.44 \\
\hline & S.D. & 0.03 & 0.04 & 0.08 & 0.04 & 0.08 & \\
\hline \multirow[t]{2}{*}{ \#6 } & Avg. & 1.99 & 7.01 & 7.61 & 5.70 & 77.12 & 99.43 \\
\hline & S.D. & 0.02 & 0.06 & 0.04 & 0.02 & 0.08 & \\
\hline \multirow[t]{2}{*}{$\# 7$} & Avg. & 1.99 & 7.01 & 7.61 & 5.70 & 77.12 & 99.43 \\
\hline & S.D. & 0.02 & 0.06 & 0.04 & 0.02 & 0.08 & \\
\hline \multirow[t]{2}{*}{$\# 8$} & Avg. & 1.99 & 7.01 & 7.66 & 5.76 & 77.02 & 99.43 \\
\hline & S.D. & 0.01 & 0.05 & 0.11 & 0.04 & 0.11 & \\
\hline \multirow[t]{2}{*}{$\# 9$} & Avg. & 2.01 & 7.04 & 7.67 & 5.71 & 77.01 & 99.44 \\
\hline & S.D. & 0.01 & 0.03 & 0.05 & 0.03 & 0.08 & \\
\hline \multirow[t]{2}{*}{$\# 10$} & Avg. & 1.99 & 7.00 & 7.71 & 5.67 & 77.07 & 99.44 \\
\hline & S.D. & 0.02 & 0.05 & 0.08 & 0.05 & 0.14 & \\
\hline \multirow{2}{*}{$\# 11$} & Avg. & 2.00 & 6.99 & 7.65 & 5.68 & 77.12 & 99.45 \\
\hline & S.D. & 0.02 & 0.08 & 0.08 & 0.03 & 0.16 & \\
\hline Powder & Avg. & 2.01 & 7.00 & 7.66 & 5.69 & 77.16 & \\
\hline & S.D. & 0.02 & 0.06 & 0.03 & 0.05 & 0.11 & \\
\hline Consecutive & Avg. & 1.99 & 6.99 & 7.67 & 5.68 & 77.11 & 99.43 \\
\hline Samples & S.D. & 0.02 & 0.04 & 0.04 & 0.04 & 0.08 & \\
\hline
\end{tabular}

A statistical analysis of the data was conducted by B.J. Hardy using the JMP software. The data obtained has been included in this report as appendices D-1 to D-3. Appendix D-1 plots show the estimators for the lot means, the $95 \%$ confidence levels for the lot means and the ratio of the between and within lot variances for the 11 lots. The tables give the $\mathrm{F}$ ratio for the between and within lot variance, the corresponding probability for $\mathrm{F}$ values greater than those obtained are shown. If the probability that $\mathrm{F}$ exceeds the calculated $\mathrm{F}$ ratio is less than 0.05 there is likely there is likely a significant difference in the compositions between lots. All components other than $\mathrm{B}_{2} \mathrm{O}_{3}$ show a significant variation between the lots.

Appendix D-2 presents similar plots and tables, except that lots 1,2, and 3 have been removed. Using the same criterion only the $\mathrm{Na}_{2} \mathrm{O}$ and $\mathrm{SiO}_{2}$ show significant variations between the lots. It should be noted these differences are very small, about $0.1 \mathrm{wt} \%$ for $\mathrm{SiO}_{2}$ and $0.05 \mathrm{wt} \%$ for $\mathrm{Na}_{2} \mathrm{O}$. 
This is within the limits of the chemical analysis. Another way to state this is that a major portion of the variability in the analysis was due to variability in the chemical analysis compared to the variability between the sub-lots.

The final plots in Appendix D-3 show the correlation between the different components. High degrees of correlation are indicated in the plots whose $95 \%$ density ellipses are stretched in a diagonal. Uncorrelated variables possess nearly round density ellipses. Quantitatively the correlations which approach 1.0 are correlated and those which approach 0.0 are uncorrelated.

It should be noted that $\mathrm{X}$-ray diffraction analysis indicated the presence of a small amount of lithium silicate, $\left(\mathrm{Li}_{2} \mathrm{SiO}_{5}\right)$ and probably $B$-Quartz. This may be cause for some concern about the dissolution of the materials prior to the chemical analyses. However, the CELS analyses of the discs from the odd sub-lots did not show any evidence of any problems.

\section{Acknowledgments}

The authors wish to acknowledge the following people for their assistance on this project. Lee Young of Ferro Corporation who oversaw the manufacture and sampling of the discs.

\section{References}

1. R.F. Schumacher, "Review of DWPF Frit Procurement and Justification of Second Frit Vendor-(U)," WSRC-TR-93-069 Rev.0, February 1, 1993. 
This page intentionally left blank. 


\section{Appendix A}

Glass Sample: DWPF LIMS \# 12354 - Lot 6, Frit 202 7/2/93

Lab I.D. No.: 15760-4, 1993

\begin{tabular}{|c|c|c|c|c|c|c|}
\hline Oxide & $\begin{array}{l}\text { Read1 } \\
\text { Wt.\% }\end{array}$ & $\begin{array}{l}\text { Read2 } \\
\text { Wt.\% }\end{array}$ & $\begin{array}{l}\text { Read3 } \\
\text { Wt.\% }\end{array}$ & $\begin{array}{l}\text { Average } \\
\text { Wt.\% }\end{array}$ & $\begin{array}{l}\text { Std.Dev. } \\
(n-1)\end{array}$ & Method \\
\hline $\mathrm{Al}_{2} \mathrm{O}_{3}$ & 0.35 & 0.33 & & 0.34 & 0.014 & $\mathrm{ICP}$ \\
\hline $\mathrm{B}_{2} \mathrm{O}_{3}$ & 7.87 & 7.92 & & 7.90 & 0.035 & ICP \\
\hline $\mathrm{CaO}$ & 0.071 & 0.062 & & 0.067 & 0.006 & ICP \\
\hline $\mathrm{Cl}-$ & 0.013 & $0: 015$ & 0.014 & 0.014 & 0.001 & ICP \\
\hline $\mathrm{Cr}_{2} \mathrm{O}_{3}$ & $<0.001$ & $<0.001$ & & $<0.001$ & 0.000 & $\mathrm{AA}$ \\
\hline F- & 0.007 & 0.008 & 0.006 & 0.007 & 0.001 & ICP \\
\hline $\mathrm{Fe}_{2} \mathrm{O}_{3}$ & 0.038 & 0.037 & & 0.038 & 0.001 & ICP \\
\hline $\mathrm{K}_{2} \mathrm{O}$ & 0.044 & 0.043 & & 0.04 & 0.001 & ICP \\
\hline $\mathrm{Li}_{2} \mathrm{O}$ & 6.91 & 6.89 & & 6.90 & 0.014 & ICP \\
\hline $\mathrm{MgO}$ & 1.98 & 1.97 & & 1.98 & 0.007 & ICP \\
\hline $\mathrm{MnO}_{2}$ & $<0.001$ & $<0.001$ & & $<0.001$ & 0.000 & ICP \\
\hline $\mathrm{Na} 2 \mathrm{O}$ & 5.92 & 5.92 & & 5.92 & 0.000 & $\mathrm{ICP}$ \\
\hline $\mathrm{NiO}$ & $<0.001$ & $<0.001$ & & $<0.001$ & 0.000 & $\mathrm{AA}$ \\
\hline $\mathrm{PbO}$ & $<0.001$ & $<0.001$ & & $<0.001$ & 0.000 & $\mathrm{AA}$ \\
\hline $\mathrm{SiO} 2$ & 76.2 & 76.0 & & 76.1 & 0.141 & ICP \\
\hline $\mathrm{TiO}_{2}$ & 0.012 & 0.012 & & 0.012 & 0.000 & ICP \\
\hline $\begin{array}{l}\text { LOI } \\
@ 600^{\circ} \mathrm{C}\end{array}$ & $C^{0.20}$ & 0.17 & 0.30 & 0.22 & 0.021 & LOI \\
\hline Total & & & & 99.53 & & \\
\hline $\begin{array}{l}\text { LOD@ } \\
110^{\circ} \mathrm{C}\end{array}$ & 0.05 & 0.02 & 0.11 & 0.06 & 0.021 & LOD \\
\hline $\mathrm{COD}$ & $<580 \mathrm{ug} / \mathrm{g}$ & & & $0.022 \%$ & & $\mathrm{COF}$ \\
\hline
\end{tabular}




\section{OfFERRO}

ELECTRONIC A SPECIALTY OLASS

FRIT DIVISION

FERRO CORPORATION

4150 EABT БQTH STREET

P.O. BOX 8660

CLEVELAND OHIO 44101

TELEPHONE (218) 641-8680

FACSIMILE (216) 641-8867)

April 28, 1994

Ray Schumacher

Wegtinghouse Savannah River Company

Savannah River site

Aiken, SC 29801-0001

Dear Ray:

Approximately 20800 piecea were made, weighing roughly 293 pounds. The product was divided into eleven sublots. The shipping date was May 1, 1994 and the carrier was Carolina Motor Freight

Copies of the actual analysis are included.

The following is a technical summary describing the process used to manufacture the discs.

1.) Milling

-performed at E\&SG Dept., Frit Div., Ferro Corp.

- Four mill turns

-52 galion unibody high alumina mill

$-75 \mathrm{~kg}$ of product (F 202) each turn

$-204 \mathrm{~kg}$ media load, high alumina 13/16" media

- $75 \mathrm{ml}$ of methanol alcohol added as a milling aid

-mili time was between 7 and 8 hours

- milling target was 68-74\% minus 325 mesh

-actualiy the milis were 79.5\%, 70.3\%, 79.4\% and $63.3 \%$ - Ior an average of $73,1 \%$

- mili turns were blended by hand prior to shipping

-the product was designated F 202 PRF in E\&SG records

2.) Spray Drying

-performed at Elan Technology a Division of Mansol Industries, Inc.

- the entire $300 \mathrm{Kgs}$ of milled material were

slurried together in one mixer, an excellent method of homogenizing

-24 ft diameter spray dryer was used, spray drying time was about 25 minutes

- organic binder was added at $4:$ level 
3.) Pressing

-performed at Elan Technology

- the green size was 1.13 inches in diameter

-the pressing was done on a ten ton Denison Presg

-pressing force is not controlled, but green weight and the dimension parallel with the force applied are metered

- the ten continuous sampleg were taken roughly half way through the pressing campaign, two sets of samples were taken

-at this point the production run was broken into eleven sublots

4.) Firing

-performed at Elan Technology

- the Eiring schedule is included on Eigure 1

- the discs were fired on ceramic plates, disca were laid flat on these plates

- the fired/final size was nominally one inch

- each disc was roughly 6 grams

- the continuous gamples were fired in the proper sequence

-the sublots were fired in order

-a total of 20850 discs were made

5.) Sampling

a. powder samples

- $1 \mathrm{~kg}$ of powdex was taken prior to spray drying and after milling - eight 40 gram samplea were taken and pent for analyais

b. regular production samples

- taken after firing

- seven or eight samples sent out for analysis

- four of the Beven samples were taken by Elan personnel from the beginning of the sublot as the sublot emerged from the furnace

- the remainder of the sample set was taken randomly from the aublot by Ferro personnel

c. continuous samples

- taken prior to firing but after pressing

- two sets of ten samples were taken directly as they came off the press

- samplea taken about half way through pressing run and were fired at the corresponding time

6.) Analysis

-Spectrochemical Laboratories, Inc, performed all 


\section{App. B}

of the analyses

-all analysis were run consistently and were reported in order of completion

- the powder samples were suppose to be run throughout the entire 'analysis run', but instead were run with the firgt eight sublot:

- all the analyses were done by plasma jet ICP?

- the actual analyses are included

- table I is an initial analysis done by the author

- the order of analysis can be found on the analysis, on the top right corner under "Our Lab\#"

Table 1 is broken down by sublot and type of sample. Averages and standard deviations were calculated. Also a aimple statistical tool, the chi squared test, was employed to determine if there were significant differences between sublot averages. Also, the same tool was used to determine if: the were significant differences between the individual mosurements. In both caseg, no significant differences were $\therefore \rightarrow d a d$.

Whank you for your business and if you need any further information or have any queations, please do not hesitate to call. me at (216) 641-8585 x6568.

sincerely,

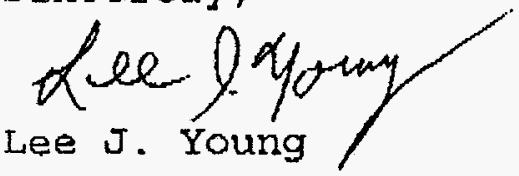

cc:\L Dunning, T Whang, W. Cunningham, E. Stadnicar 
TABLE 1

\begin{tabular}{|c|c|c|c|c|c|c|c|}
\hline Sublot & $\left|\begin{array}{c}\text { Weight } \\
\text { (Kgs) }\end{array}\right|$ & Count & $\begin{array}{l}\text { Mgo } \\
(\%)\end{array}$ & $\begin{array}{l}\mathrm{Li} 20 \\
(\%)\end{array}$ & $\begin{array}{c}\mathrm{B2O3} \\
(\%)\end{array}$ & $\begin{array}{c}\mathrm{Na2O} \\
(\%)\end{array}$ & $\begin{array}{l}S i O_{2} \\
(\%)\end{array}$ \\
\hline 1 AVG & 11.6 & 1800 & 2.02 & 6.90 & 7.64 & 5.59 & 77.24 \\
\hline STD & & & 0.03 & & & & 0.19 \\
\hline 2 AVG & 11.9 & 1850 & 202 & 6.95 & 7.67 & 5.67 & 77.08 \\
\hline STD & & & 903 & 0.07 & 0.08 & 0.06 & 0.13 \\
\hline$A V G$ & 12.5 & 1950 & 203 & 7.07 & 701 & 5.73 & 76.96 \\
\hline STD & & & 0.05 & 0.07 & 0.05 & 0.12 & 0.2 \\
\hline 4 AVG & 10.7 & 1650 & 2.00 & 7.07 & 7.66 & 5.71 & 76.96 \\
\hline STD & & & 0.02 & 0.04 & 0.07 & 0.05 & 0.11 \\
\hline 5 AVG & 8.7 & 1350 & 2.01 & 7.00 & 7.67 & 5.74 & 77.00 \\
\hline STD & & & 0.03 & 0.03 & 0.06 & 0.07 & 0.11 \\
\hline 6 AVG & 12.3 & 1900 & 1.98 & 7.01 & 7.60 & 5.68 & 77.18 \\
\hline STD & & & 0.02 & 0.04 & 7 & 0.04 & 0.07 \\
\hline $7 \mathrm{AVG}$ & 10.1 & 1600 & 1.99 & 7.01 & 7.61 & 5.70 & 77.12 \\
\hline $\begin{array}{l}73 \\
\ldots \\
\ldots\end{array}$ & & & 0.01 & 0.06 & 0.04 & 0.02 & 0.07 \\
\hline 8 & 17.5 & 2750 & 1.99 & 7.01 & 7.66 & 5.76 & 77.02 \\
\hline STD & & & 0.01 & 0.05 & 0.1 & 0.03 & 0.1 \\
\hline 9 AVG & 12.4 & $1950^{\circ}$ & 201 & 7.04 & 7.67 & 5.71 & 77.10 \\
\hline STD & & & 0.01 & 0.03 & 0.04 & 0.03 & 0.25 \\
\hline 10 AVG & 12 & 1900 & 1.99 & 7.00 & 7.71 & 5.67 & 77.07 \\
\hline STD & & & 0.02 & 0.04 & 0.08 & 0.05 & 0.13 \\
\hline \multirow{2}{*}{$\begin{array}{c}11 \text { AVG } \\
\text { STD }\end{array}$} & 13.5 & 2150 & 2.00 & 6.99 & 7.65 & 5.68 & 77.12 \\
\hline & & & 0.02 & 0.08 & 0,08 & 0.03 & 0.14 \\
\hline \multirow[t]{2}{*}{ continuous } & AVG & 10 & 1.99 & 6.99 & 7.67 & 5.68 & 77.11 \\
\hline & STO & & 0.02 & 0.04 & 0.04 & 0.03 & 0.07 \\
\hline \multirow[t]{2}{*}{ powder } & AVG & & 2.02 & 7.00 & 7.67 & 5.69 & 77.14 \\
\hline & STO & & 0.03 & 0.06 & 0.07 & 0.07 & 0.13 \\
\hline \multirow[t]{2}{*}{ production } & AVG & & 2.00 & 7.00 & 7.6 & 5.70 & 77.08 \\
\hline & STD & & 0.03 & 0.07 & 0.08 & 0.07 & 0.17 \\
\hline \multicolumn{3}{|c|}{ chi squared on avgs } & 0.001 & 0003 & 0.001 & 0.011 & 0.001 \\
\hline \multicolumn{3}{|c|}{ chi squared on indlvid } & 0.037 & 059 & 0.06 & 0.075 & 0.029 \\
\hline \multicolumn{3}{|c|}{ results of chi squared tests } & No & NS & NS & NS & NS \\
\hline TOTAL & 133.2 & 20850 & & & & cant & \\
\hline
\end{tabular}




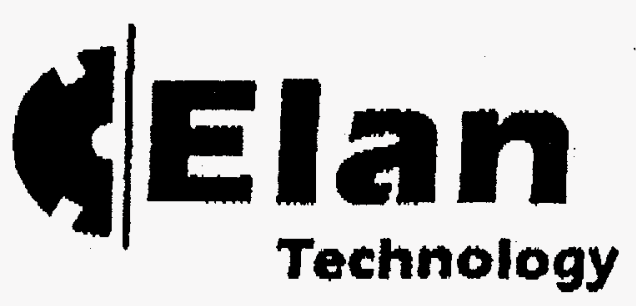

App. B

Tu: Ferro

Att: Lee J. Young

From: Walter B. Reed

Fax: 216.641 .8857

Date: $5 / 3 / 94$

Pages: 1

Ref: Our phone conversution yesterday.

Below is the profite for firtng part \#310004.

Furnace \#3

$\begin{array}{ll}\text { Zone 1 } & 450^{\circ} \mathrm{F} \\ \text { Zune 2 } & 550^{\circ} \mathrm{F} \\ \text { Zone 3 } & 650^{\circ} \mathrm{F} \\ \text { Zone 4 } & 800^{\circ} \mathrm{F} \\ \text { Zone } 5 & 1000^{\circ} \mathrm{F} \\ \text { Zone } 6 & 1150^{\circ} \mathrm{F} \\ \text { Zone } 7 & 1270^{\circ} \mathrm{F} \\ \text { Zone } 8 & 1290^{\circ} \mathrm{F}\end{array}$

Belt speed 10 inches per minute

Raw pressing 0.260 to 0.265

Best Regurds,

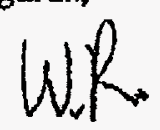

140 Little Street, Belleville, NJ 07109-3295 - Tel:(201)759-8600 - Fax:(201)751-2506 
Tolophone: 412-371-2345

FAX: 412.371-0463

Ferro Corporation

4150 East 56th Street

P.0. Box 6550

Cleveland, Ohio 44101

Attn: Mr. Lee Young

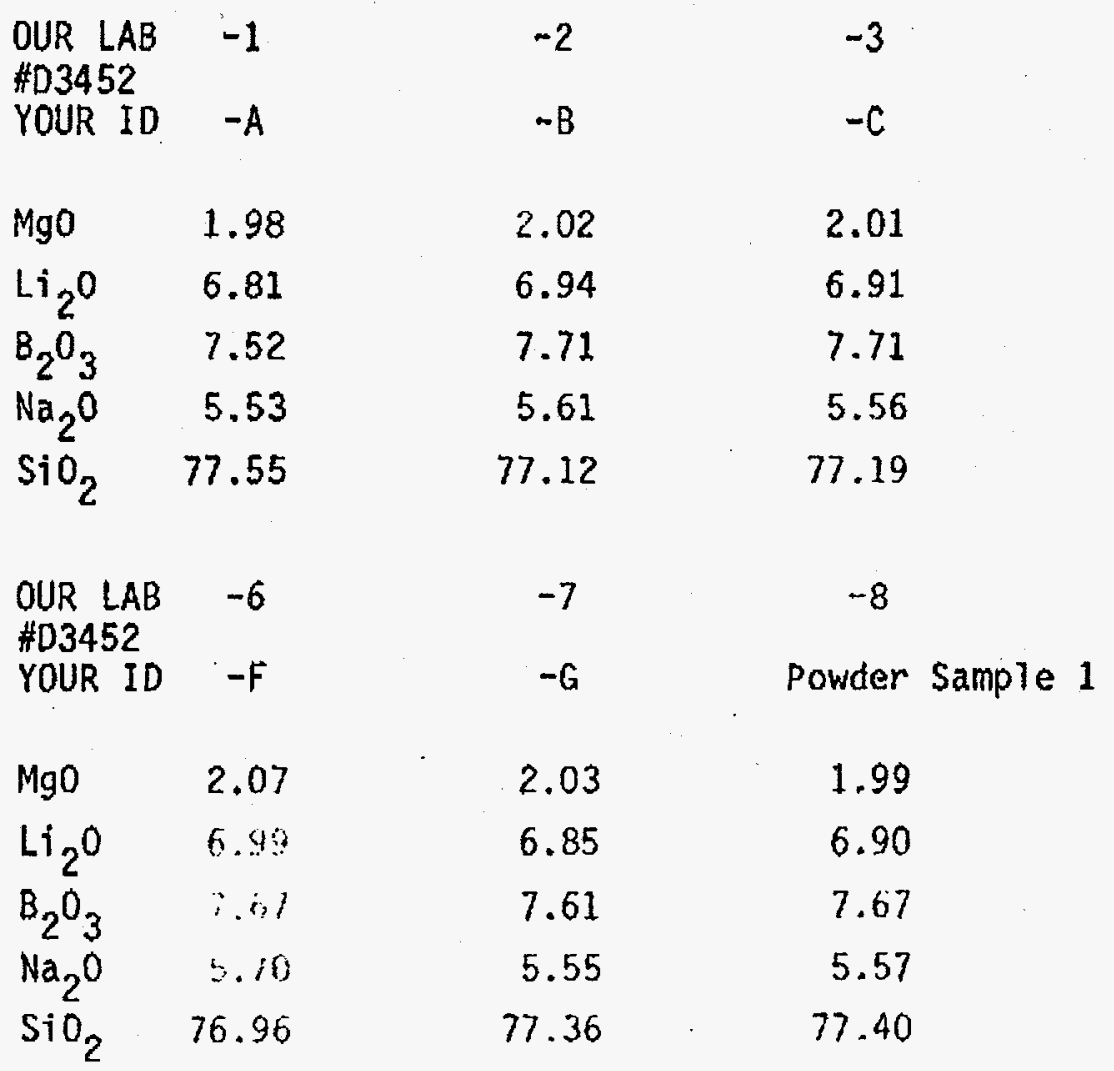

635O FRANKSTOWN AVENUE PITTSBUROH, PA. I5221

Apri1 25, 1994

Sample recd. 4-5-94

Your Req. \# AR 764

Your Charge\# EG59273

Our Lab\#D3452
ANALYSIS REPORT

RESULTS IN WEIGHT $q$

F202 PRF Sublot 1

$\begin{array}{ll}-4 & -5 \\ -D & -E\end{array}$

2.03

1.99

6.97

6.83

7.62

7.65

5.69

5.52

77.07

77.41

SPECTROTIFMICAL LABORATORIES, InC.

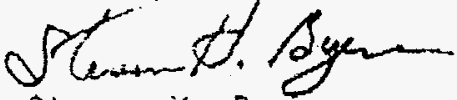

Stevien is. Byers 
Telephone: 412-371-2345

FAX: 412374.0463

Ferro Corporation

4150 East 56th Street

P.0. Box 6550

Cleveland, Ohio 44101

Attn: Mr. Lee Young
\$350 FRANKSTOWN AVENUE PITTSaUROH, PA. 15221

Aprī 25, 1994

Sample recd. 4-5-94

Your Req.\# AR 764

Your Charge\# EG59273

Our Lab\#D3453

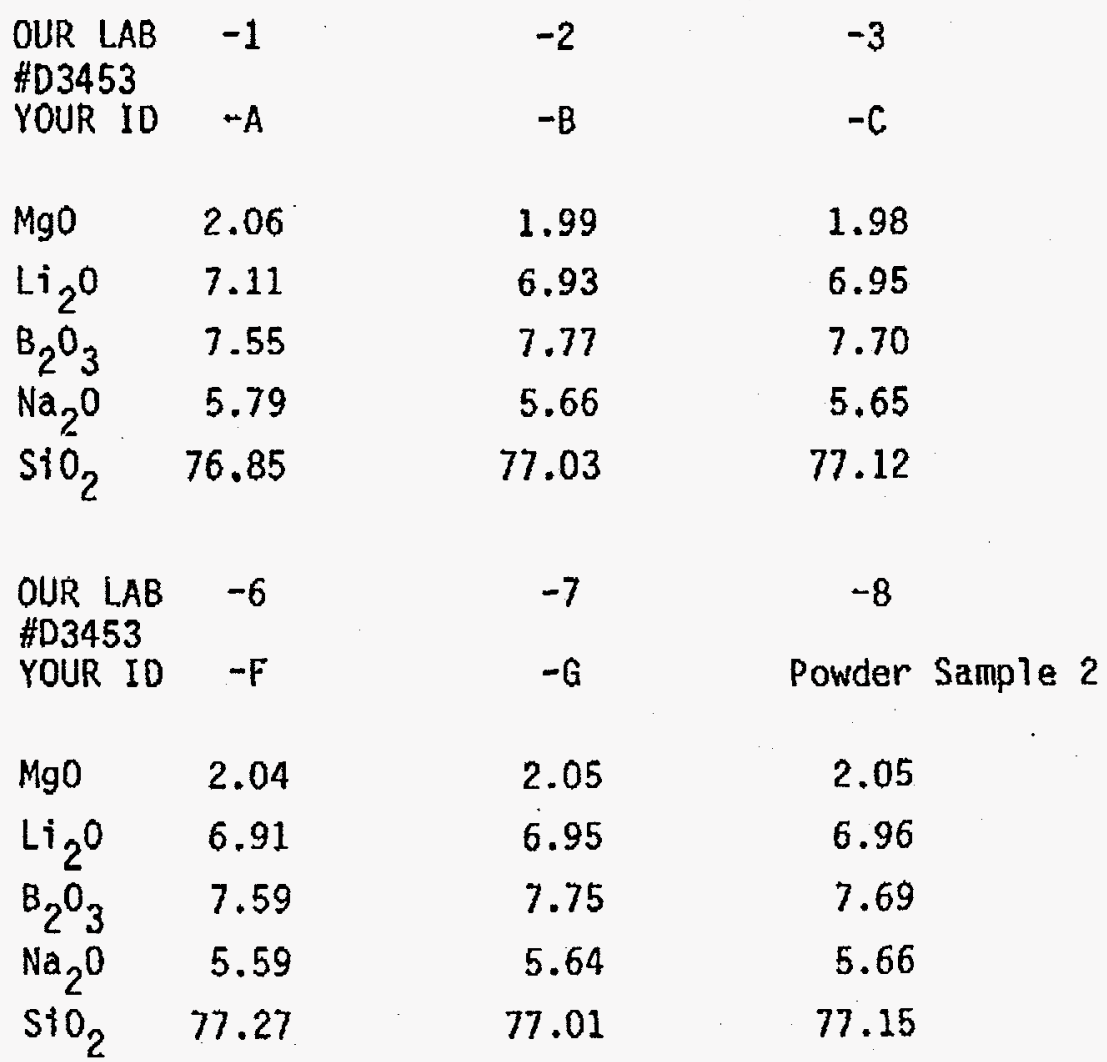

ANALYSIS REPORT

RESULTS IN WEIGHT :

F202 PRF Sublot 2

$\begin{array}{ll}-4 & -5 \\ -D & -E\end{array}$

2.02

2.00

6.91

6.91

7.70

7.61

5.68

5.65

77.08

77.23

SPECTROCHEMICAL LABORATORIES, InC.

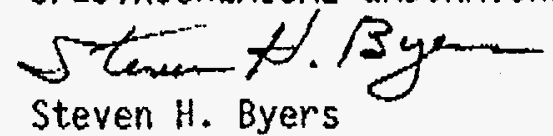




\section{Spectrochemical Laboratories, Ine.}

Tolephone: 412-371-2345

FAX: 442-374-0463

Ferro Corporation 4150 East 56 th Street

P.0. Box 6550

Cleveland, Ohio 44101

Attn: Mr. Lee Young
B350 FRANKSTOWN AVENUE

PItTsBUROH, PA. IS221

Aprit 25, 1994

Sample recd. 4-5-94

Your Req.\#AR 764

Your Charge EG59273

Our Lab\#D3454 $\begin{array}{ll}\text { OUR LAB } & -1 \\ \text { \#D3454 } & \\ \text { YOUR ID } & -A\end{array}$

MgO

$\mathrm{Li}_{2} \mathrm{O}$

$\mathrm{B}_{2} \mathrm{O}_{3}$

$\mathrm{Na}_{2} \mathrm{O}$

$\mathrm{SiO}_{2} \quad 76.25 \cdot 4$

OUR LAB $\quad-6$

\#D3454

YOUR ID $-F$

MgO $\quad 1.96$

$\mathrm{Li}_{2} \mathrm{O}$

$\mathrm{B}_{2} \mathrm{O}_{3}$

$\mathrm{Na}_{2} \mathrm{O}$

7.02

7.68

5.69

$\mathrm{SiO}_{2} \quad 77.07$

ANALYSIS REPORT

RESULTS IN WEIGHT \&

F202 PRF Sublot 3

$-2$

$-B$

2.02

7.05

7.68

5.60

77.06
$-3$

$-C$

1.97

7.03

7.60

5.55

77.25

$-8$

Powder Sample 3

2.02

7.06

7.58

5.77

76.97
$-4$

-D

2.08

7.05

7.60

5.71

76.96
$-5$

$-E$

2.10

7.23

7.55

5.94

76.56

SPECTROCHEMICAL LABORATORIES, InC.

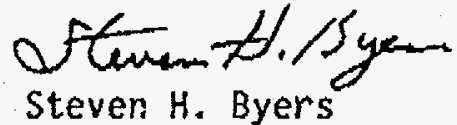


Tolephone: 412-371-2345

FAX: 412-374-0463

Ferro Corporation

4150 East 56 th Street

P. 0. Box 6550

Cleveland, Ohio 44101

Attn: Mr. Lee Young
935O FRANKSTOWN AVENUE PITTSBURGH, PA. 15321

April 25, 1994

Sample recd. 4-5-94

Your Req.\# AR 764

Your Charge\# EG59273

Our Lab\#D3455
ANALYSIS REPORT

RESULTS IN WEIGHT \%

F202 PRF Sublot 4
76.93

YOUR ID $-F$

$\mathrm{MgO}$

2.00

7.13

$\mathrm{B}_{2} \mathrm{O}_{3}$

$\mathrm{Na}_{2} \mathrm{O}$

7.75

5.70

$\mathrm{SiO}_{2} \quad 76.83$
$\mathrm{Li}_{2} \mathrm{O}$
$-2$

$-B$

2.00

7.05

7.63

5.79

$-7$

$-G$

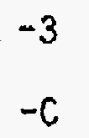

2.01

7.03

7.72

5.67

76.97

$-8$

Powder Sample 4

1.96

7.08

7.70

5.74

76.94

$\begin{array}{ll}-4 & -5 \\ -0 & -E\end{array}$

2.04

1.99

7.02

7.13

7.53

7.69

5.62

5.72

77.19

76.88
SPECTROCHEMICAL LABORATORIES, Ine.

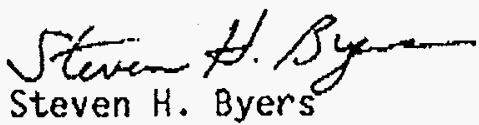


Tolephone: 412-371-2345

FAX: 412-371-0461

Ferro Corporation

4150 East 56 th Street

P.0. Box 6550

Cleveland, Ohio 44101

Attn: Mr. Lee Young
6350 FRANKSTOWN AVENUE PItT\$BLROH, PA, 15221

April 25, 1994

Sample recd. 4-5-94

Your Req.\# AR 764

Your Charge\# EG59273

Our Lab\# D3456
ANALYSIS REPORT

\section{RESULTS IN WEIGHT :}

F202 PRF Sub7ot 5

\begin{tabular}{|c|c|c|c|}
\hline \multirow{2}{*}{$\begin{array}{l}\text { OUR LAB } \\
\text { \#D } 3456 \\
\text { YOUR ID }\end{array}$} & -1 & -2 & -3 \\
\hline & $-A$ & $-B$ & $-c$ \\
\hline $\mathrm{MgO}$ & 2.01 & 2.05 & 1.99 \\
\hline $\mathrm{Li}_{2} \mathrm{O}$ & 7.02 & 7.06 & 6.97 \\
\hline$B_{2} 0_{3}$ & 7.55 & 7.66 & 7.69 \\
\hline $\mathrm{Na}_{2} \mathrm{O}$ & 5.73 & 5.85 & 5.79 \\
\hline $\mathrm{SiO}_{2}$ & 77.11 & 76.80 & 76.99 \\
\hline $\begin{array}{l}\text { OUR LAB } \\
\text { \#D3456 }\end{array}$ & -6 & -7 & -8 \\
\hline YOUR ID & $-F$ & $-G$ & Powder Sample 5 \\
\hline $\mathrm{MgO}$ & 2.01 & 1.96 & 2.06 \\
\hline $\mathrm{Li}_{2} \mathrm{O}$ & 6.97 & 7.02 & 6.96 \\
\hline $\mathrm{B}_{2} \mathrm{O}_{3}$ & 7.65 & 7.76 & 7.75 \\
\hline $\mathrm{Na}_{2} \mathrm{O}$ & 5.66 & 5.80 & 5.72 \\
\hline $\mathrm{SiO}_{2}$ & 77.13 & 76.90 & 77.03 \\
\hline
\end{tabular}

SPECTROCHEMICAL LABORATORIES, InC.

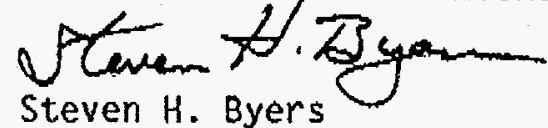


Spectrachemical Labaratories, 7ne. ApP. B

Tolephones $412-371-2345$

FAX: 412-374-0463

Ferro Corporation

4150 East 56 th Street.

P.0. Box 6550

Cleveland, Ohio 44101

Attn: Mr. Lee Young
6350 FRANKSTOWN AVENUE PITTSBUROH, PA. 15221

Apri1 25, 1994

Sample recd. 4-5-94

Your Req.\# AR 764

Your Charge\# EG59273

Our Lab\#D3457

\section{ANALYSIS REPORT}

\section{RESULTS IN HEIGHT \%}

F202 PRF Sublot 6

\begin{tabular}{|c|c|c|c|}
\hline $\begin{array}{l}\text { OUR LAB } \\
\text { HD3457 } \\
\text { YOUR ID }\end{array}$ & $\begin{array}{l}-1 \\
-A\end{array}$ & $\begin{array}{l}-2 \\
-8\end{array}$ & $\begin{array}{l}-3 \\
-6\end{array}$ \\
\hline $\mathrm{MgO}$ & 2.01 & 1.96 & 2.00 \\
\hline $\mathrm{Li}_{2} \mathrm{O}$ & 6.95 & 7.01 & 7.00 \\
\hline $\mathrm{B}_{2} \mathrm{O}_{3}$ & $7: 71$ & 7.61 & 7.58 \\
\hline $\mathrm{Na}_{2} \mathrm{O}$ & 5.72 & 5.72 & 5.65 \\
\hline $\mathrm{SiO}_{2}$ & 77.05 & 77.17 & 77.22 \\
\hline $\begin{array}{l}\text { OUR LAB } \\
\text { \#D } 3457 \\
\text { YOUR ID }\end{array}$ & $\begin{array}{l}-6 \\
-5\end{array}$ & $\begin{array}{l}-7 \\
-6\end{array}$ & -8 \\
\hline $\mathrm{MgO}$ & 1.97 & 2.00 & 2.00 \\
\hline $\mathrm{Li}_{2} \mathrm{O}$ & 6.98 & 7.07 & 7.09 \\
\hline$B_{2} D_{3}$ & 7.65 & 7.50 & 7.54 \\
\hline $\mathrm{Na}_{2} \mathrm{O}$ & 5.69 & 5.70 & 5.72 \\
\hline $\mathrm{SiO}_{2}$ & 77.16 & 77.17 & 77.17 \\
\hline
\end{tabular}

$-4$

$-5$

$-0$

$-E$

1.99

1.94

6.99

7.06

7.50

7.64

5.66

5.62

77.30

77.16

SPECTROCHEMICAL LABORATORIES, InC.

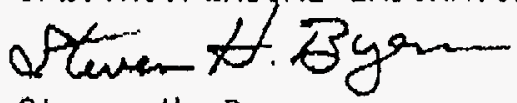

Steven $H$. Byers 
Spectrachemical Labarataries, Ine. App. B

Tolephoner 412-371.2345

FAX: 412-371-0463

Ferro Corporation

4150 East 56 th Street

P.0. Box 6550

Cleveland, Ohio 44101

Attn: Mr. Lee Young
6350 FRANKSTOWN AVENUE PITISBUROH, PA. 15221

April 25, 1994

Sample recd. 4-5-94

Your Req.\# AR 764

Your Charge\# EG59273

Our LabłD3458
ANALYSIS REPORT

\section{RESULTS IN WEIGHT \%}

F202 PRF sublot 7

\begin{tabular}{|c|c|c|c|}
\hline $\begin{array}{l}\text { OUR LAB } \\
\text { HD3458 } \\
\text { YOUR ID }\end{array}$ & $\begin{array}{l}-1 \\
-A\end{array}$ & $\begin{array}{l}-2 \\
-B\end{array}$ & $\begin{array}{l}-3 \\
-C\end{array}$ \\
\hline $\mathrm{MgO}$ & 1.97 & 2.00 & 1.99 \\
\hline $\operatorname{Li}_{2} 0$ & 6.88 & 7.02 & 7.04 \\
\hline $\mathrm{B}_{2} \mathrm{O}_{3}$ & 7.63 & 7.60 & 7.68 \\
\hline $\mathrm{Na}_{2} \mathrm{O}$ & 6.73 & 5.71 & 5.69 \\
\hline $\mathrm{SiO}_{2}$ & 77.24 & 77.07 & 77.04 \\
\hline $\begin{array}{l}\text { OUR LAB } \\
\text { \#D3458 } \\
\text { YO11 }\end{array}$ & $\begin{array}{l}-6 \\
-F\end{array}$ & -7 & -8 \\
\hline YOUK ID & $-F$ & $-G$ & Powder Sample 7 \\
\hline $\mathrm{MgO}$ & 2.00 & 2.01 & 2.00 \\
\hline $\mathrm{Li}_{2} \mathrm{O}$ & 7.01 & 7.05 & 6.99 \\
\hline $\mathrm{B}_{2} \mathrm{O}_{3}$ & 7.56 & 7.62 & 7.65 \\
\hline $\mathrm{Na}_{2} \mathrm{O}$ & 5.68 & 5.70 & 5.66 \\
\hline $\mathrm{SiO}_{2}$ & 77.19 & 77.05 & 77.21 \\
\hline
\end{tabular}

$-4 \quad-5$

$-D \quad-E$

$2.00 \quad 1.97$

$7.08 \quad 6.98$

$7.60 \quad 7.58$

$5.68 \quad 5.74$

$\begin{array}{ll}77.08 & 77.17\end{array}$

SPECTROCHEMICAL LABORATORIES, InC.

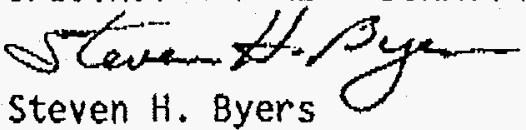


Ferro Corporation

4150 East 56 th Street

P.0. Box 6550

Cleveland, Ohio 44101

Attn: Mr. Lee Young

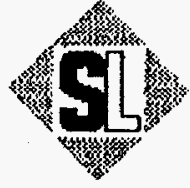

April 25, 1994

Sample recd, 4-5-94

Your Req. \# AR 764

Your Charge\# EG59273

our Lab\#D3459

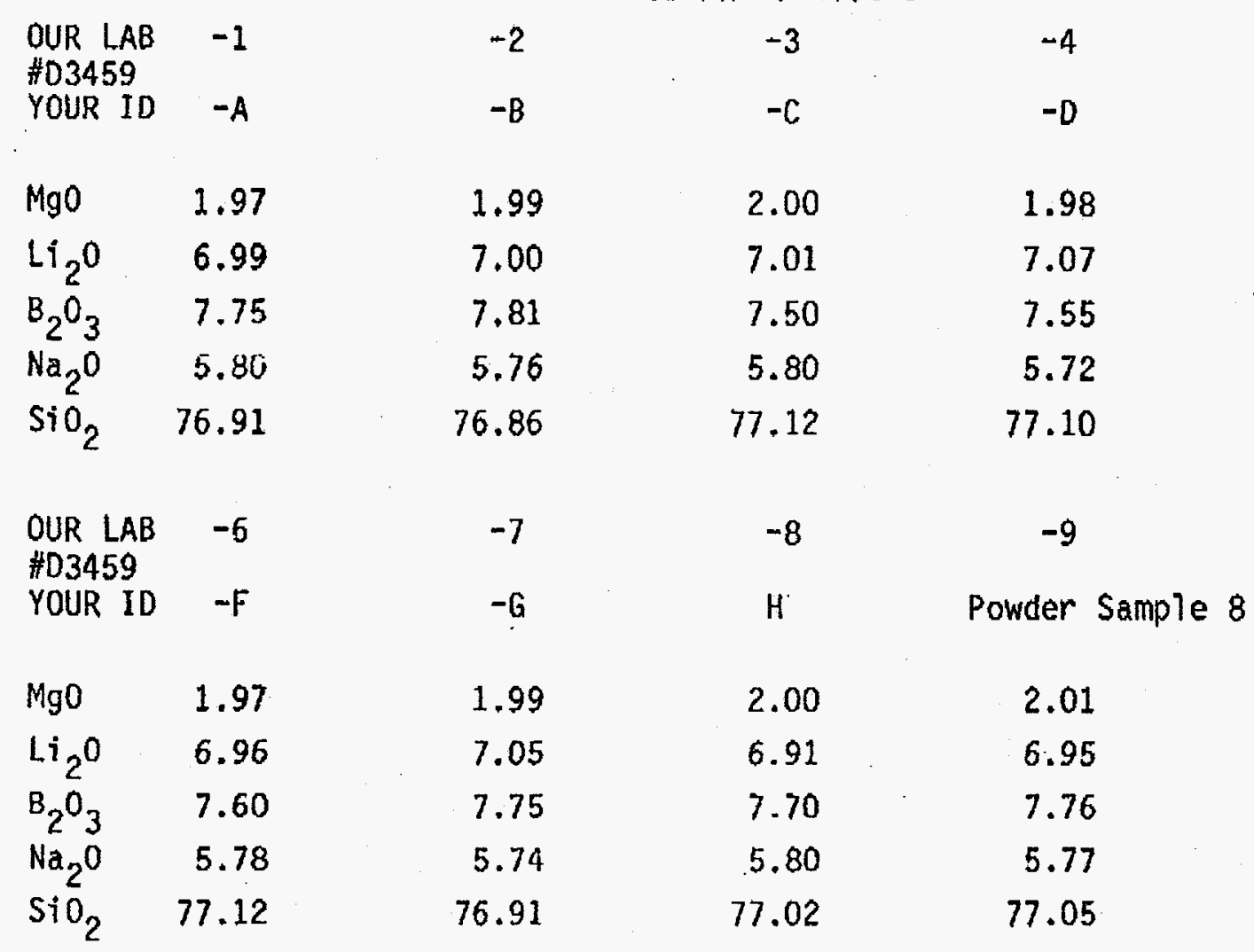

ANALYSIS REPORT

RESULTS IN WEIGHT \&

F202 PRF Sublot 8

SPECTROCHEMICAL LABORATORIES, InC.

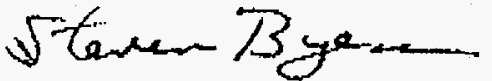

Steven $H$. Byers 


\section{Spectrochemical Laborataries, 7ne. ApP. B}

Telephoner $412-371-2345$

FAX: 412-374-0463

Ferro Corporation

4150 East 56 th Street

P.0. Box 6550

Cleveland, Ohio 44101

Attn: Mr. Lee Young
9950 FRANKSTOWN AVENUE PIITSBURGH, PA. 15221

Apr 1725,1994

Sample recd, 4-5-94

Your Req.\# AR 764

Your Charge\# EG59273

Our Lab\#D3460
ANALYSIS REPORT

RESULTS IN WEIGHT \%

F202 PRF Sublot 9

\begin{tabular}{|c|c|c|}
\hline $\begin{array}{l}\text { OUR LAB } \\
\text { \#D3460 } \\
\text { YOUR ID }\end{array}$ & $\begin{array}{l}-1 \\
-A\end{array}$ & $\begin{array}{l}-2 \\
-B\end{array}$ \\
\hline $\mathrm{MgO}$ & 2.01 & 2.01 \\
\hline $\mathrm{Li}_{2} \mathrm{O}$ & 7.08 & 7.07 \\
\hline $\mathrm{B}_{2} \mathrm{O}_{3}$ & 7.71 & 7.67 \\
\hline $\mathrm{Na}_{2} \mathrm{O}$ & 5.74 & 5.72 \\
\hline $\mathrm{SiO}_{2}$ & 76.90 & 76.96 \\
\hline $\begin{array}{l}\text { OUR LAB } \\
\# D\end{array}$ & -6 & -7 \\
\hline YOUR ID & $-F$ & $-G$ \\
\hline $\mathrm{MgO}$ & 1.99 & 2.02 \\
\hline $\mathrm{Li}_{2} \mathrm{O}$ & 7.02 & 7.03 \\
\hline $\mathrm{B}_{2} \mathrm{O}_{3}$ & 7.66 & 7.60 \\
\hline $\mathrm{Na}_{2} \mathrm{O}$ & 5.70 & 5.66 \\
\hline $\mathrm{SiO}_{2}$ & 77.08 & 77.13 \\
\hline
\end{tabular}

$-3$

$-4$

$-5$

$-D$

$-E$

2.02

2.02

2.00

7.04

7.05

7.00

7.72

7.62

7.71

5.73

5.72

5.68

76.93

77.03

77.06

SPECTROCHEMICAL LABORATORIES, InC.

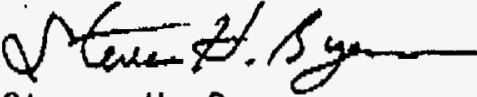

Steven $H$. Byers 


\section{Spectrochemical Labaratories. Inc.}

App. B

Wlaphono: 412-371-2345

FAX: 412-371-0468

Ferro Corporation

4150 East 56th Street

P.0. Box 6550

Cleveland, Ohio 44101

Attn: Mr. Lee Young

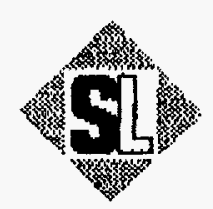

ANALYSIS REPORT

RESULTS IN MEIGHT \%

F202 PRF Subiot 10

$-2$

$-B$

1.99

6.97

7.57

5.72

77.20

$-7$

$-G$

HD3461

YOUR ID $-F$

Mgo $\quad 1.98$

2.03

$\mathrm{Li}_{2} \mathrm{O}$

$\mathrm{B}_{2} \mathrm{O}_{3}$

$\mathrm{Na}_{2} \mathrm{O}$

7.04

7.05

7.78

5.69

76.90

$\begin{array}{lll}\mathrm{SiO}_{2} & 77.10 & 76.90\end{array}$

8350 FRANKSTOWN AVENUE PITTSBUROH, PA, 15271

April 25, 1994

Sample recd. 4-5-94

Your Req. \# AR 764

Your Charge\# EG59273

Our Lab\#D3461

SPECTROCHEMICAL LABORATORIES, InC.

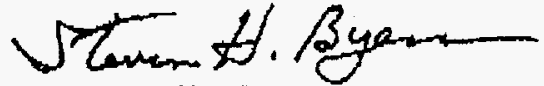

Steven $H$. Byers 
Spectrochemical Labarataries, Ine. APP. B

Tolephone: $412-371-2345$

FAX: 412.371 .0463

Ferro Corporation

4150 East 56 th Street

P.0. Box 6550

Cleveland, Ohio 44101

Attn: Mr. Lee Young
6350 FRANKSTOWN AVENUE PITTSQUROH, PA. 15221

April 25, 1994

Sample recd. 4-5-94

Your Req. AR 764

Your Charge\# EG59273

our Lab \#D3462
ANALYSIS REPORT

RESULTS IN WEIGHT \% F202 PRF Sublot 11

\begin{tabular}{|c|c|c|}
\hline $\begin{array}{l}\text { OUR LAB } \\
\text { \#D3462 } \\
\text { YOUR ID }\end{array}$ & $\begin{array}{l}-1 \\
-A\end{array}$ & $\begin{array}{l}-2 \\
-B\end{array}$ \\
\hline $\mathrm{MgO}$ & 1.95 & 2.02 \\
\hline $\operatorname{Li}_{2} 0$ & 6.82 & 6.95 \\
\hline $\mathrm{B}_{2} \mathrm{O}_{3}$ & 7.60 & 7.67 \\
\hline $\mathrm{Na}_{2} \mathrm{O}$ & 5.64 & 5.69 \\
\hline $\mathrm{SiO}_{2}$ & 77.45 & 77.11 \\
\hline $\begin{array}{l}\text { OUR LAB } \\
\text { \#D3462 }\end{array}$ & $\begin{array}{l}-6 \\
-F\end{array}$ & -7 \\
\hline YOUR ID & $-F$ & $-G$ \\
\hline $\mathrm{MgO}$ & 2.01 & 1.99 \\
\hline $\mathrm{Li}_{2} \mathrm{O}$ & 7.06 & 7.01 \\
\hline $\mathrm{B}_{2} \mathrm{O}_{3}$ & 7.71 & 7.75 \\
\hline $\mathrm{Na}_{2} \mathrm{O}$ & 5.66 & 5.70 \\
\hline $\mathrm{SiO}_{2}$ & 77.00 & 77.00 \\
\hline
\end{tabular}

SPECTROCHEMICAL LABORATORIES, InC.

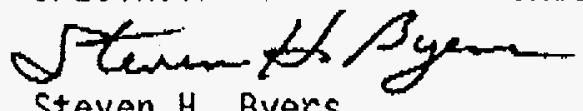

Steven H. Byers 
Tolephone: 412-371-2345

FAX: 412-371-0463

Ferro Corporation

4150 East 56 th Street

P.0. Box 6550

Cleveland, Ohio 44101

Attn: $\mathrm{Mr}$. Lee Young
3350 FRANKSTOWN AVENUE PITTSBUROH, PA. 15221

April 25, 1994

Sample recd. 4-8-94

Your Req.\# AR 764

Your Chargef EG59273

our Lab \#D3522
ANALYSIS REPORT

\section{RESULTS IN HEIGHT \&}

F202 PRF

$\begin{array}{lc}\text { OUR LAB } & -1 \\ \text { AD } 3522 & \\ \text { YOUR IO } & -4 \\ \mathrm{MgO} & : .97 \\ \mathrm{Li}_{2} \mathrm{O} & \because .4 \\ \mathrm{~B}_{2} \mathrm{O}_{3} & \cdots \\ \mathrm{Na}_{2} \mathrm{O} & 5.65 \\ \mathrm{SiO}_{2} & 77.21\end{array}$

OUR LAB -6

\#D3522

YOUR ID $-F$

$\begin{array}{lr}\mathrm{MgO} & 1.98 \\ \mathrm{Li}_{2} \mathrm{O} & 6.96 \\ \mathrm{~B}_{2} \mathrm{O}_{3} & 7.66 \\ \mathrm{Na}_{2} \mathrm{O} & 5.67 \\ \mathrm{SiO}_{2} & 77.18\end{array}$

-2
-8

2.01

6.95

7.65

5.62

77.20

$-7$

$-6$

2.01

7.02

7.65

5.73

77.03
$-3$

$-c$

2.00

6.97

7.71

5.66

77.09

$-8$

$-H$

1.99

6.97

7.63

5.70

77.15
$-4$

$-D$

1.98

6.96

7.64

5.73

77.12

$-9$

$-I$

2.00

7.03

7.74

5.67

77.00
$-5$

$-E$

1.98

6.98

7.70

5.68

77.09

$-10$

$-3$

2.02

7.08

7.63

5.69

77.02

SPECTROCHEMICAL LABORATORIES, InC.

ftement/Syensom

Steven $H$. Byers 
August 11, 1994

Mr. James E. Sproull

Westinghouse Savannah River Co. Building 704-35s

P.O. Box 516

Aiken, SC 29808

Copy to: CELS File
CELS Client No.: 11988-048

Date Received : 22-JUL-94

Date Reported

Reviewed \&

Approved by
CORNINR

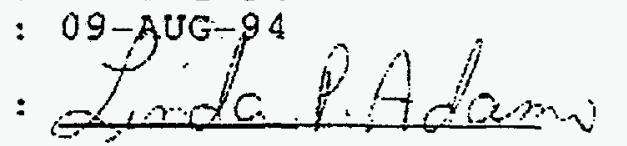

Linda P. Adams Technical sales Engineer

\section{SAMPLE IDENTIFICATION:}

\begin{tabular}{|c|c|c|c|c|c|c|}
\hline $\begin{array}{l}\text { Sample } \\
\text { Sample } \\
\text { Sample } \\
\text { Sample } \\
\text { Sample } \\
\text { Sample }\end{array}$ & $\begin{array}{l}1: \\
2: \\
3: \\
4: \\
5: \\
6:\end{array}$ & $\begin{array}{l}\text { Frit } \\
\text { Frit } \\
\text { Frit } \\
\text { Frit } \\
\text { Frit }\end{array}$ & $\begin{array}{l}202 \\
202 \\
202 \\
202 \\
202\end{array}$ & $\begin{array}{l}\text { Disk; } \\
\text { Disk; } \\
\text { Disk; } \\
\text { Disk; } \\
\text { Disk; }\end{array}$ & $\begin{array}{l}20139 ; \\
20140 ; \\
20141 ; \\
20142 ; \\
20143 ;\end{array}$ & $\begin{array}{l}\text { E57157-46-5 } \\
\text { E } 57157-46-3 \\
\text { E } 57157-46-7 \\
\text { E57157-46-11 } \\
\text { E57157-46-9 }\end{array}$ \\
\hline
\end{tabular}

\section{ANALYSIS REPORTED:}

Exhibit

A

Quantitative Chemical Analysis

B

Semi-Quantitative spectrographic Analysis

\section{COMMENTS :}

Client Purchase order No. AA07196N

Direct questions regarding this report to Linda Adams, CELs office.

NOTE: This report shall not be reproduced except in full; without the written approval of CeLs - Corning Laboratory services. 
Exhibit A: Quantitative Chemical Analysis

Sample Description:
Sample 1:
Fit 202
Sample 2:
Frit 202 Disk; 20139; $257157-46-5$
Sampie 3: Frit 202 Disk; 20141; E57157-46-7

Lab I.D. NO.: 15052-94

\section{Determination}

Results (Wt.

Test Method

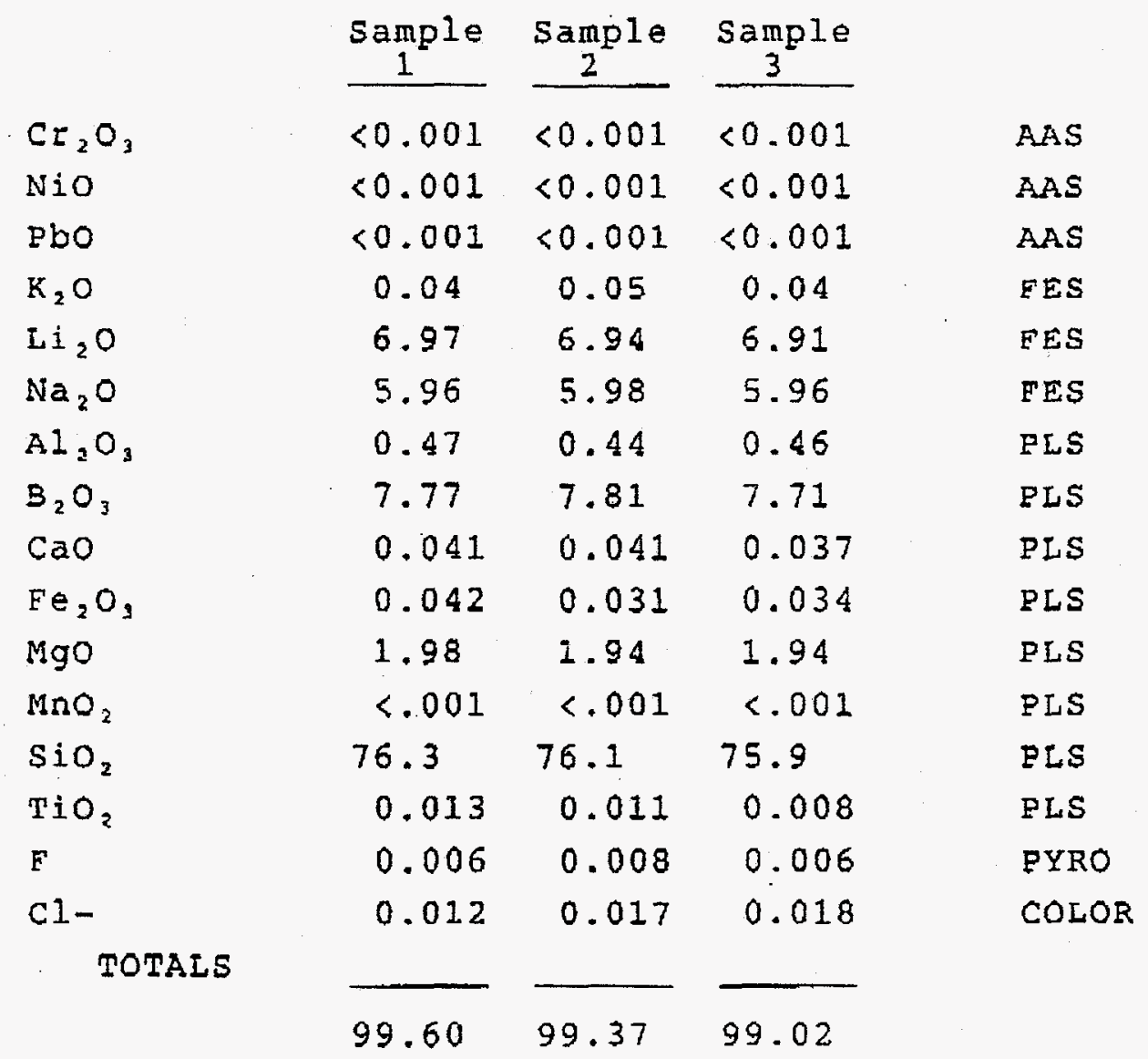

\section{LEGEND:}

AAS: Atomic Absorption spectroscopy

FES: Flame Emission Spectroscopy

PLS: Plasma/Emission Spectroscopy
PYRO: Pyrohydrolysis COLOR: Colorimetry 
CELS Client No.: 11988-048

Exhibit A: Quantitative chemical Analysis

Sample Description:

Sample 4: Frit 202 Disk; 20142; E\$7157-46-11

Sample 5: Frit 202 Disk; 20143; E57157-46-9

Sample 6: std.; NIST 93A

Lab I.D. No.: 15052-94

\begin{tabular}{|c|c|c|c|c|c|}
\hline \multirow[t]{2}{*}{ Determination } & \multicolumn{3}{|c|}{ Results (Wt.s) } & \multicolumn{2}{|c|}{ Test Method } \\
\hline & $\begin{array}{c}\text { Sample } \\
\end{array}$ & $\begin{array}{c}\text { Sample } \\
5\end{array}$ & Sample & & \\
\hline $\mathrm{Cr}_{2} \mathrm{O}_{3}$ & $<0.001$ & $<0.001$ & - & & AAS \\
\hline NiO & $<0.001$ & $<0.001$ & - & & AAS \\
\hline PbO & $<0.001$ & $<0.001$ & - & & AAS \\
\hline $\mathrm{K}_{2} \mathrm{O}$ & 0.04 & 0.04 & - & & FES \\
\hline $\mathrm{Li}_{2} \mathrm{O}$ & 6.94 & 6.97 & - & & FES \\
\hline $\mathrm{Na}_{2} \mathrm{O}$ & 5.97 & 5.97 & 4.00 & 3.98 & EES \\
\hline $\mathrm{Al}_{2} \mathrm{O}_{3}$ & 0.47 & 0.46 & 2.26 & 2.28 & PLS \\
\hline $\mathrm{B}_{2} \mathrm{O}_{3}$ & 7.73 & 7.73 & 12.6 & 12.56 & PLS \\
\hline $\mathrm{CaO}$ & 0.039 & 0.040 & - & & PLS \\
\hline $\mathrm{Fe}_{2} \mathrm{O}_{3}$ & 0.041 & 0.10 & - & & PLS \\
\hline $\mathrm{MgO}$ & 1.95 & 1.96 & - & & PLS \\
\hline $\mathrm{MnO}_{2}$ & $<.001$ & $<.001$ & - & & ELS \\
\hline $\mathrm{SiO}_{2}$ & 77.0 & 76.3 & 80.7 & 80.8 & PLS \\
\hline $\mathrm{TiO}_{2}$ & 0.011 & 0.011 & - & & PLS \\
\hline$F$ & 0.006 & 0.004 & - & & PYRO \\
\hline $\mathrm{Cl}-$ & 0.013 & 0.006 & - & & COLOR \\
\hline \multirow[t]{2}{*}{ TOTALS } & & & $\longrightarrow$ & & \\
\hline & 100.21 & 99.59 & 99.56 & & \\
\hline
\end{tabular}

\section{LEGEND:}

AAS: Atomic Absorption spectroscopy

FES: Flame Emission spectroscopy

PLS: Plasma/Emission Spectroscopy
PYRO: PYrohydrolysis COLOR: Colorimetry 


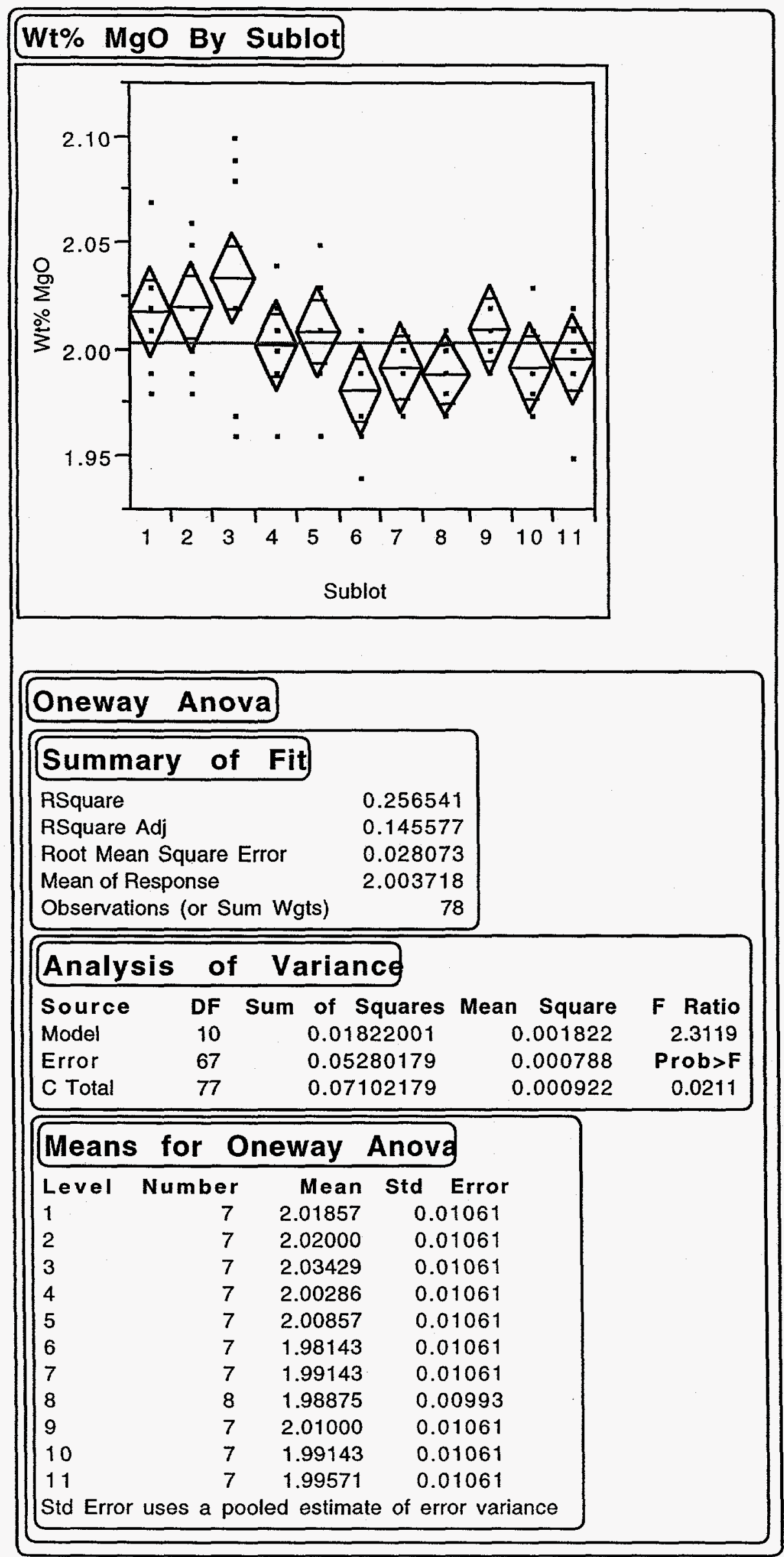

APPENDIX D-1 


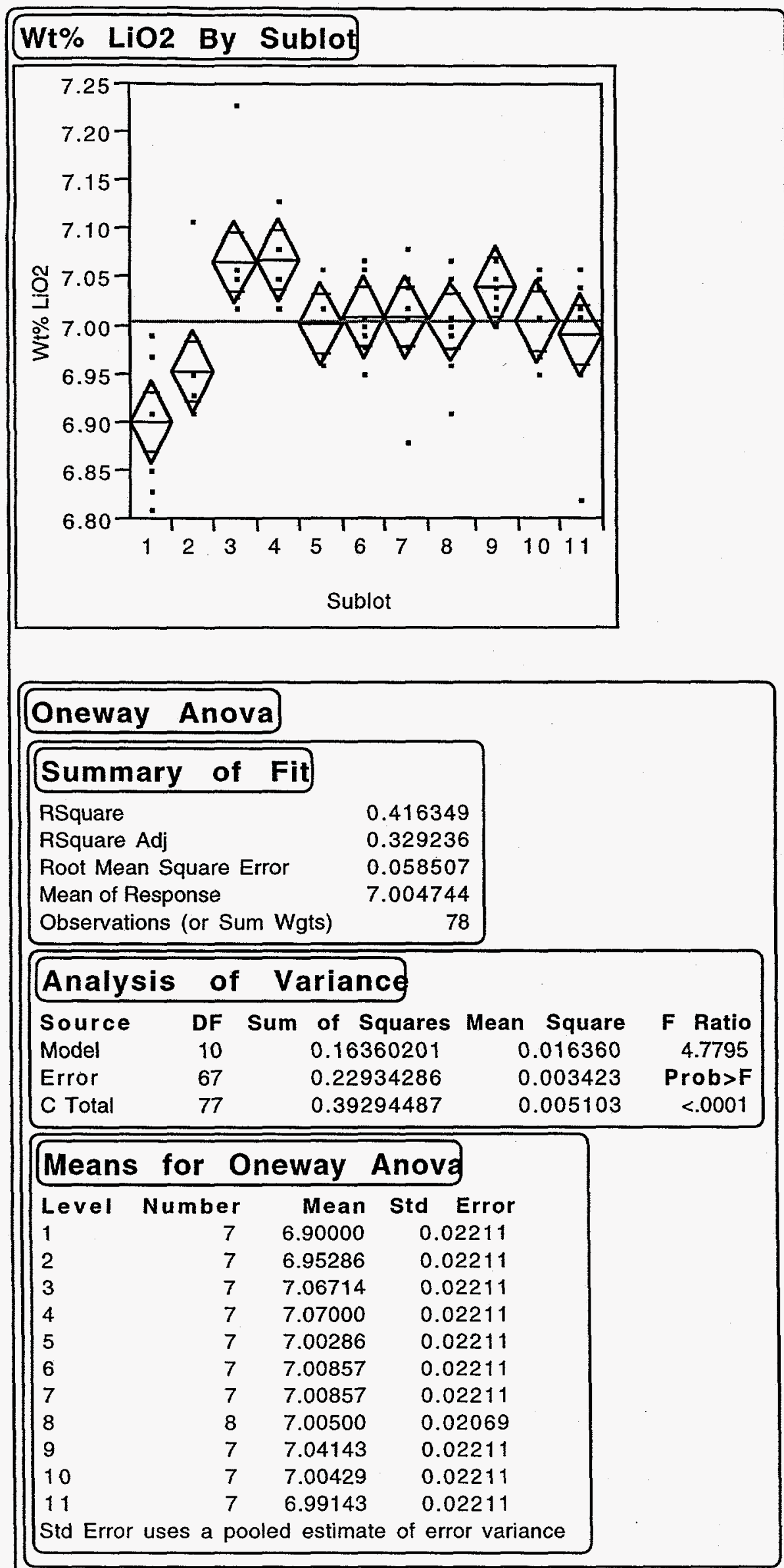




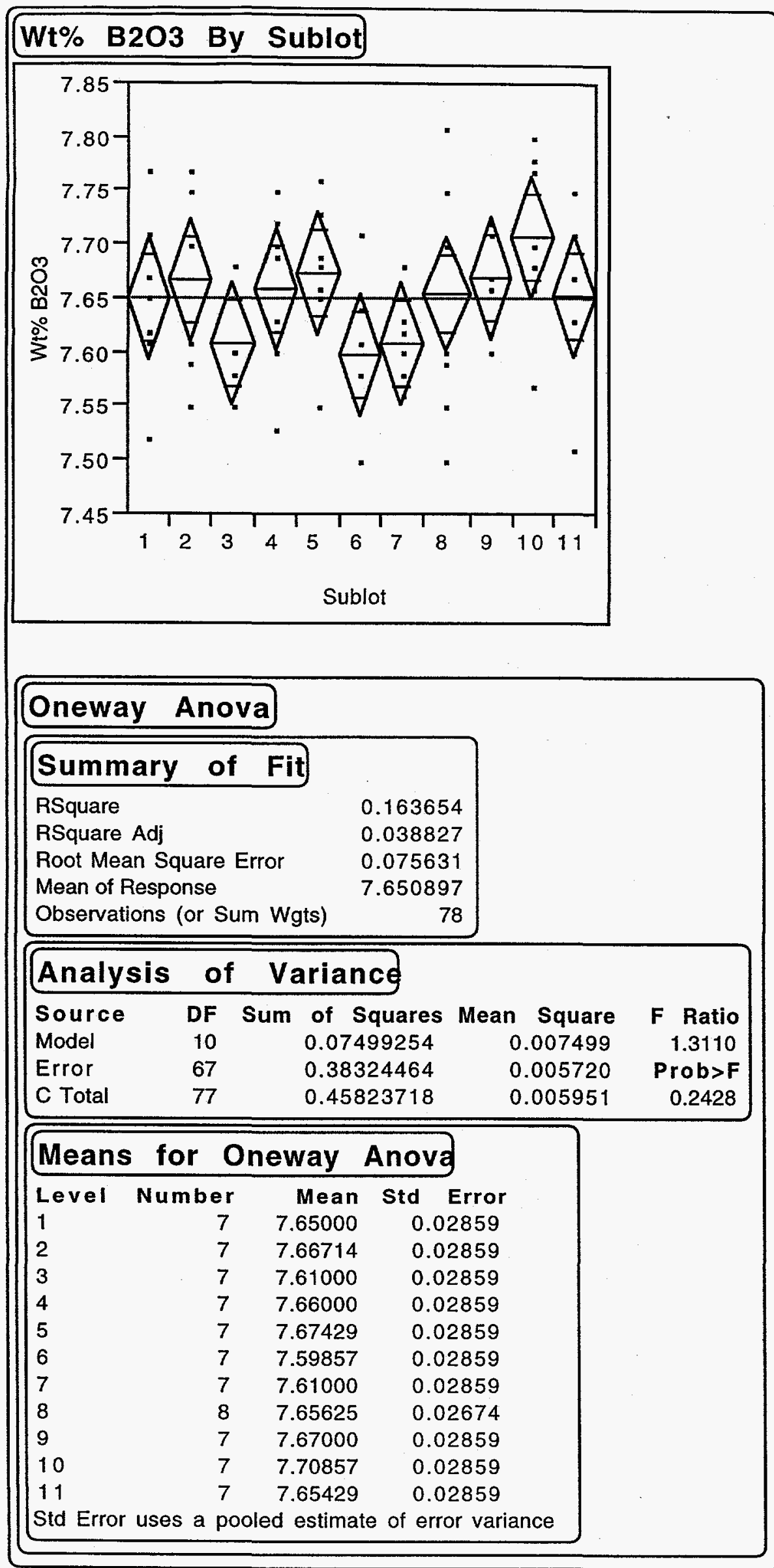

ApPEndIX D-1 


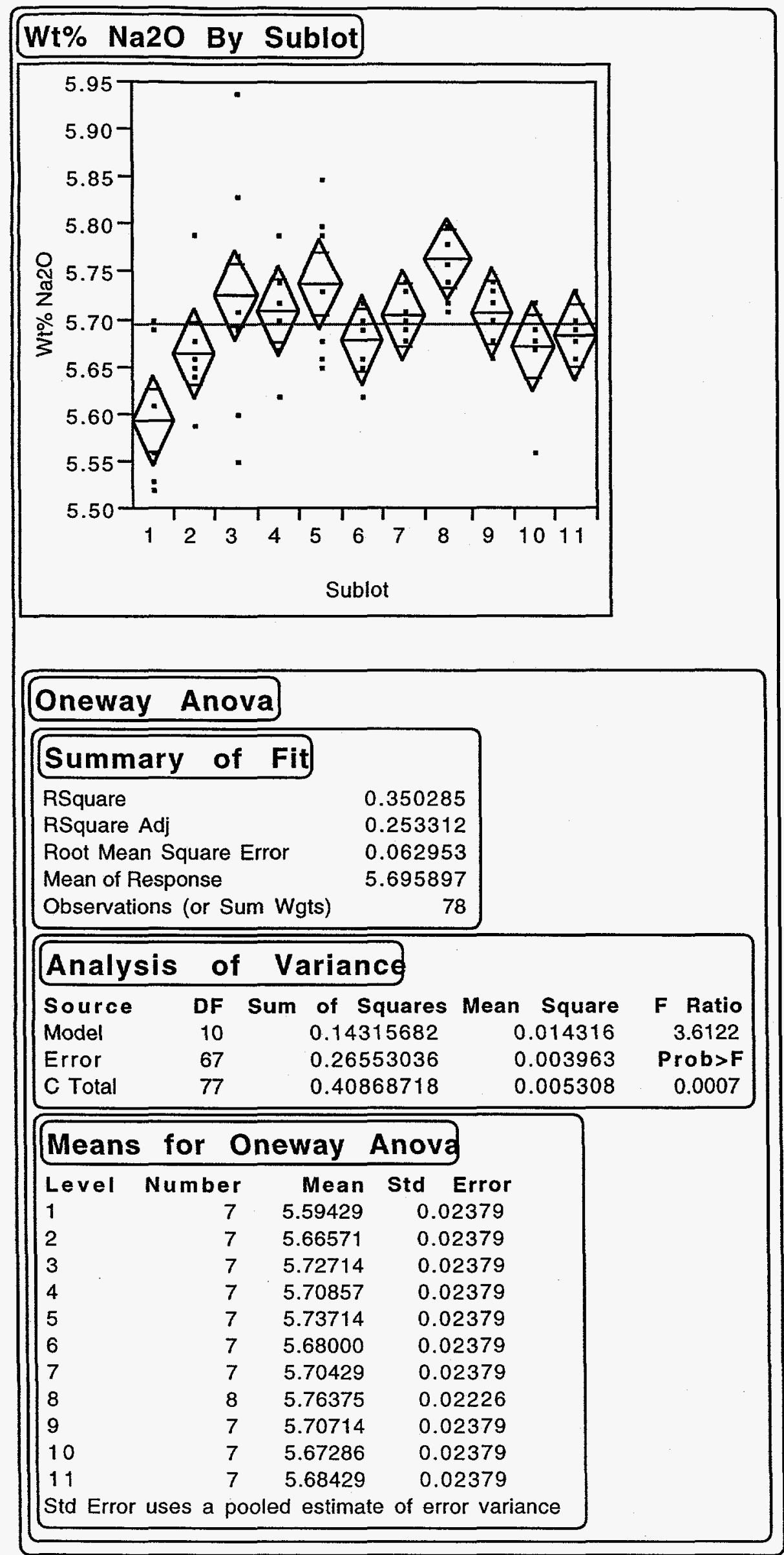

APPENDIX D- 


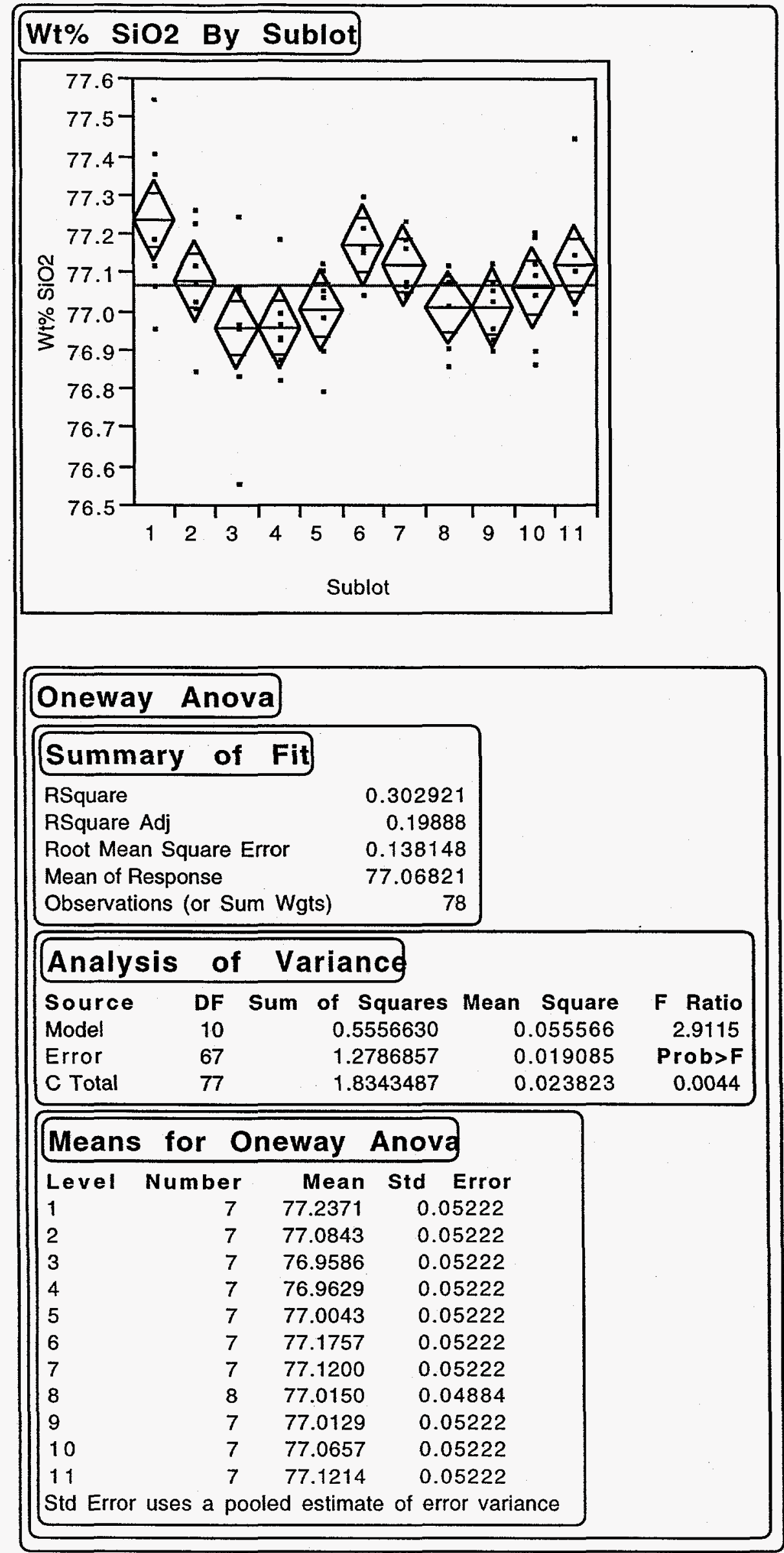

Appendix D-1 


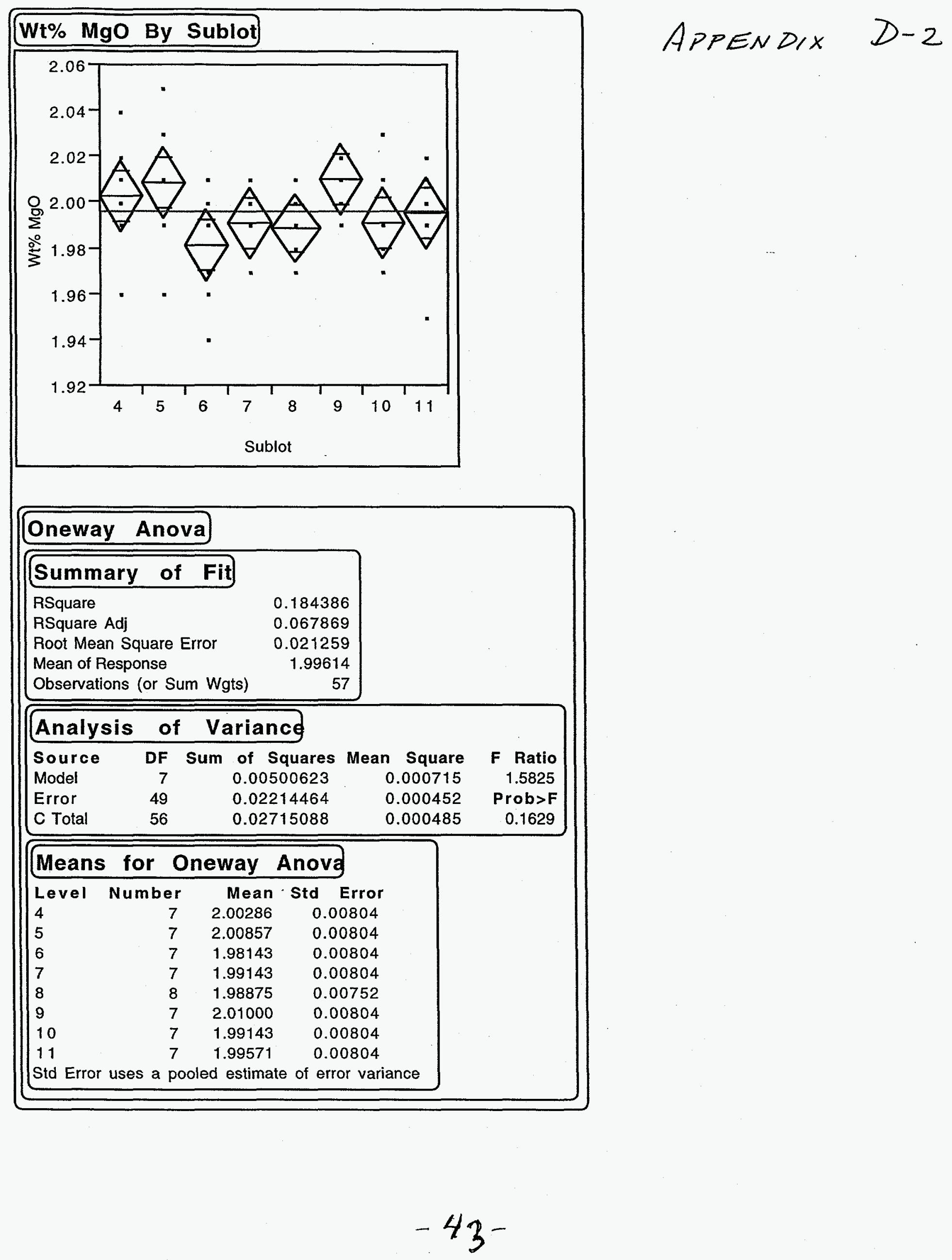




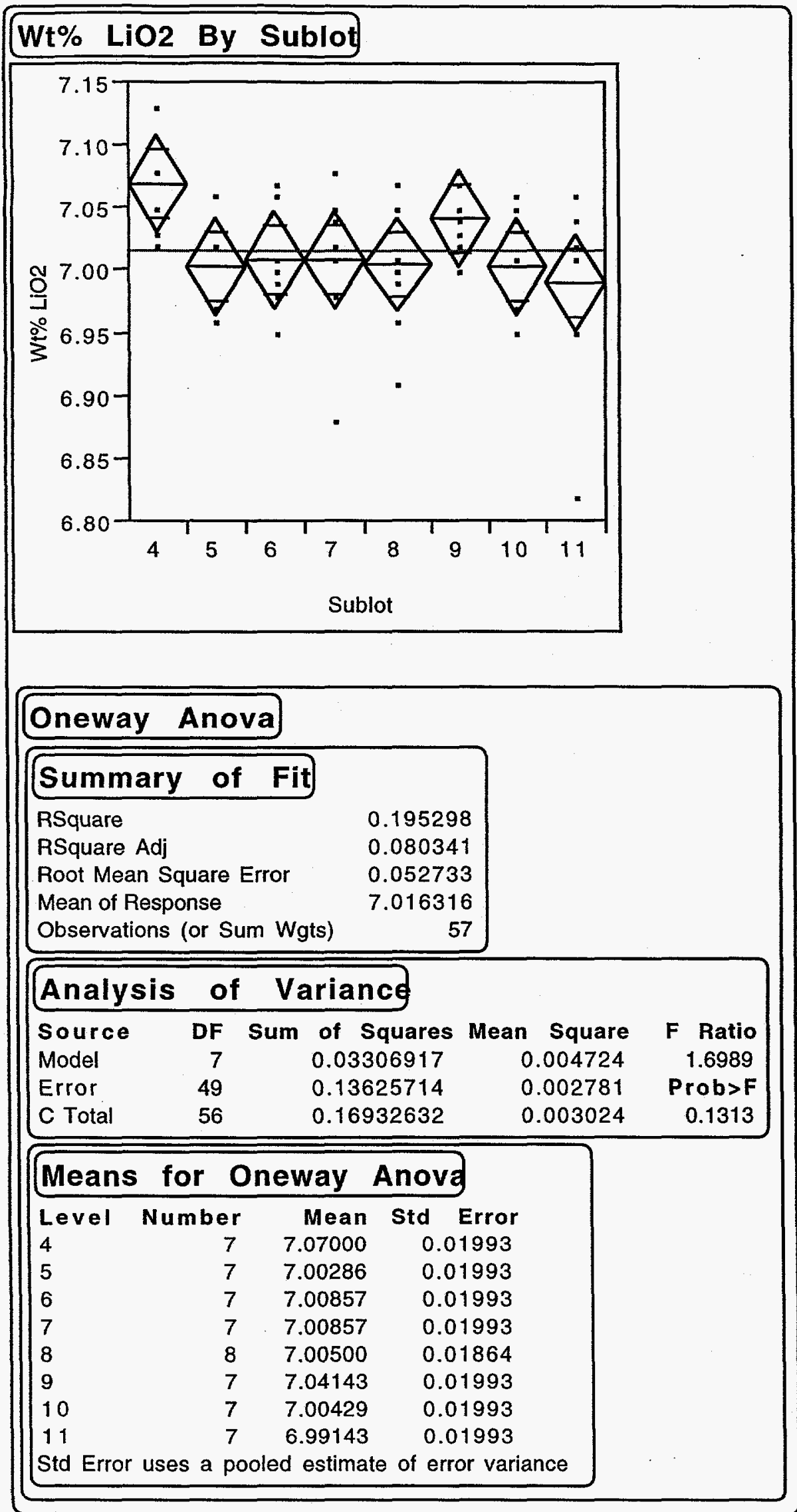




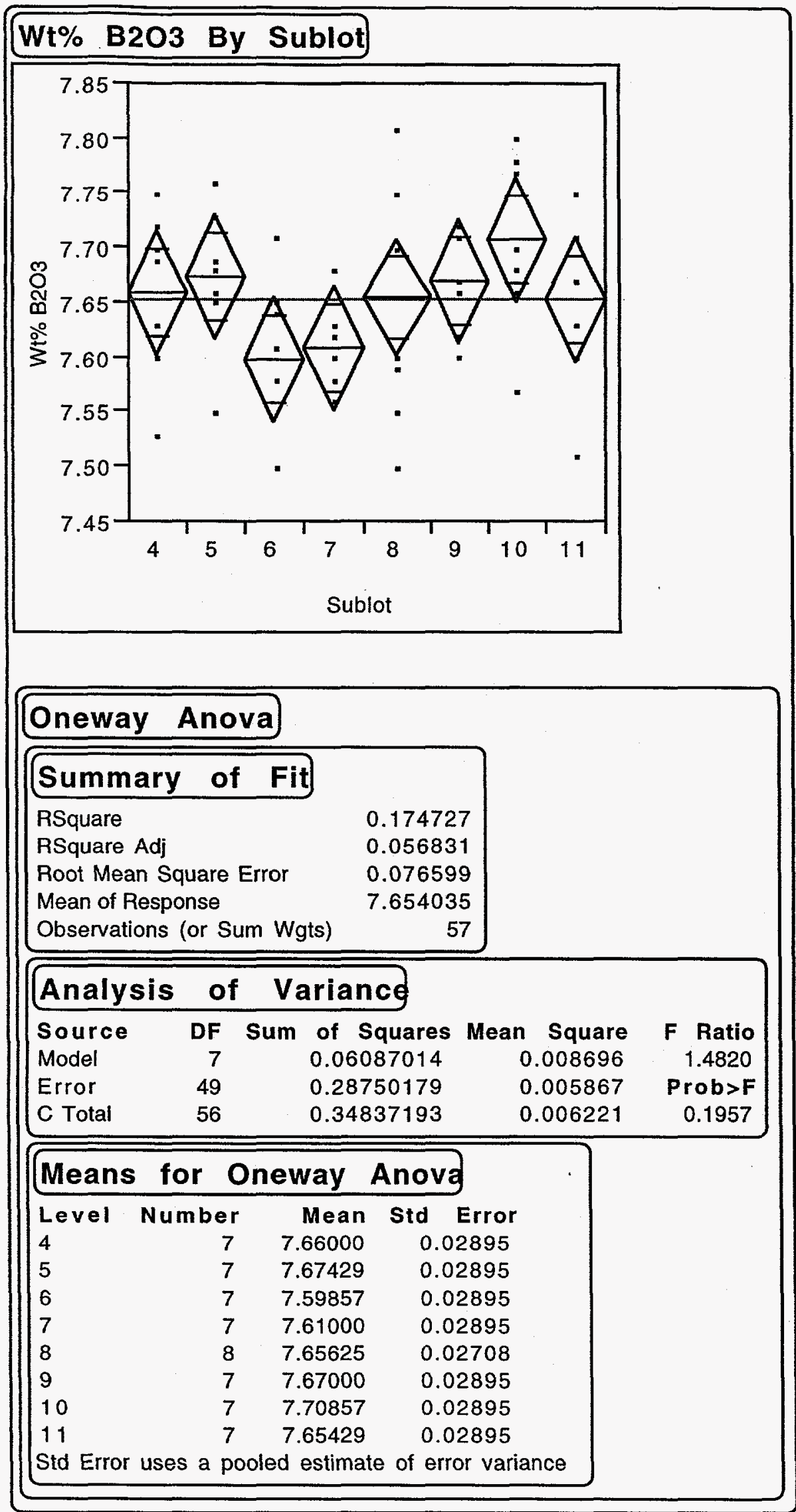

APPENDIX D-2 


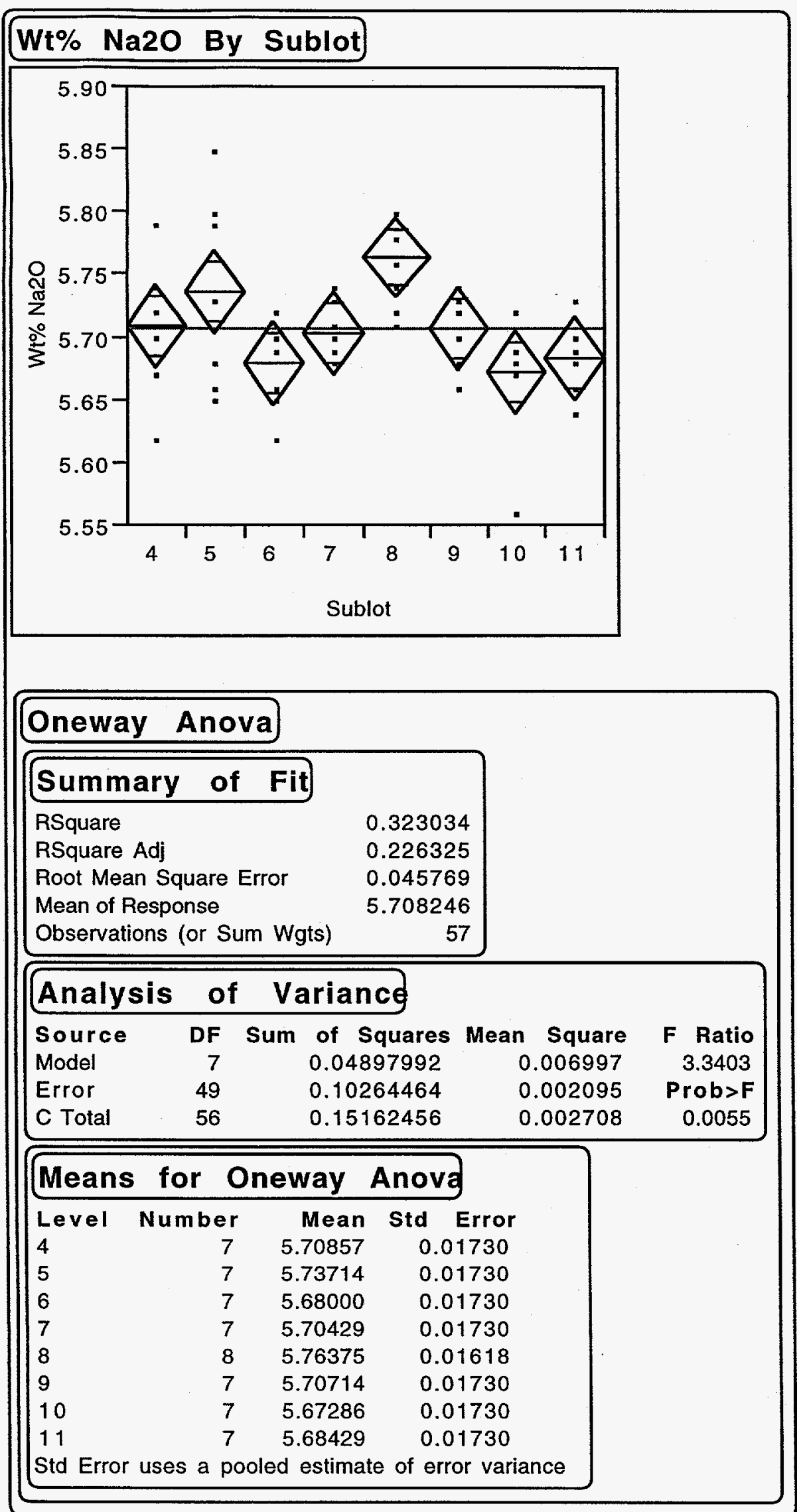




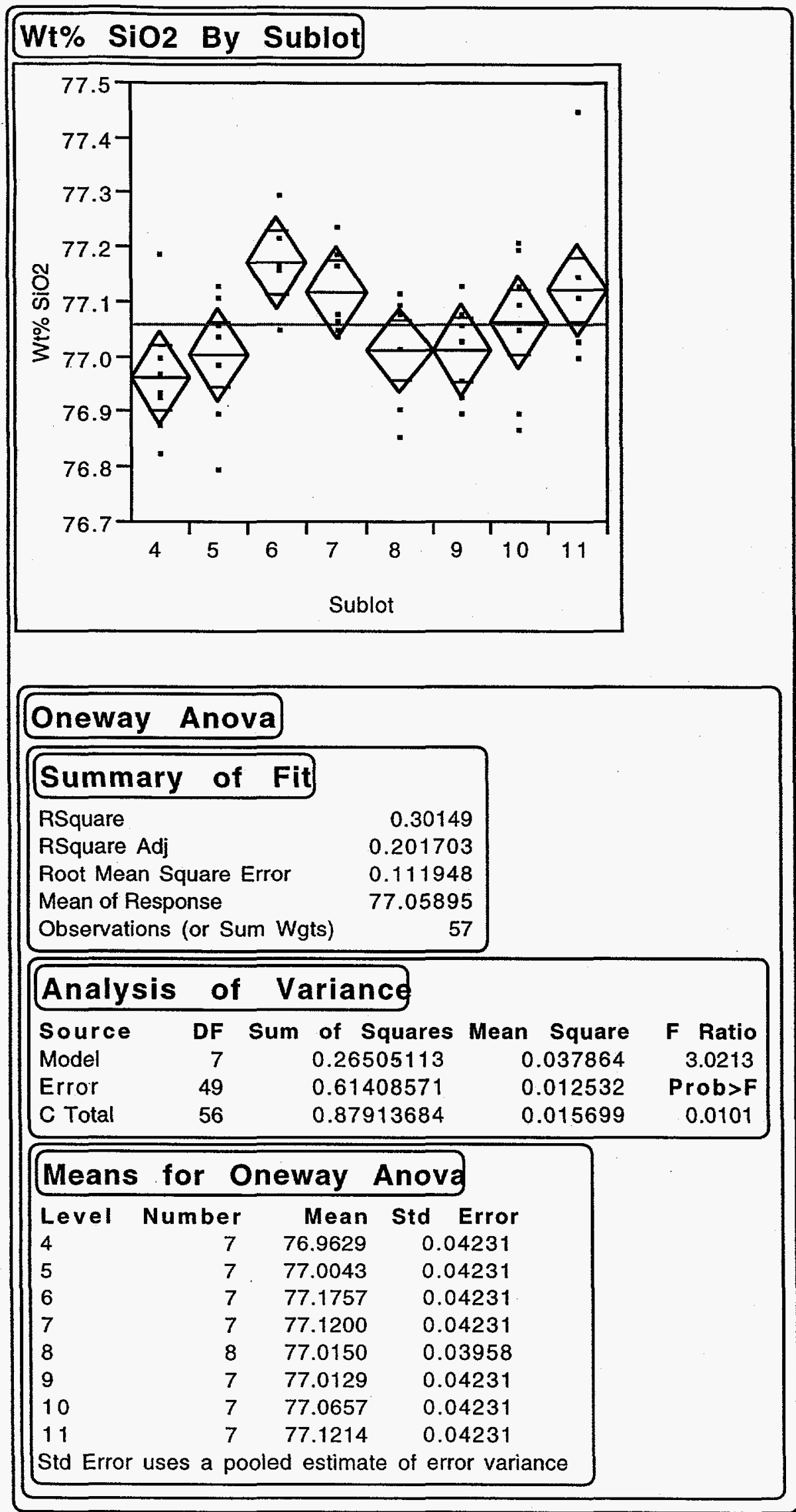

Appendix D-2 
Correlations

\begin{tabular}{|c|c|c|c|c|c|c|}
\hline \multicolumn{2}{|c|}{ Variable } & Wt\% MgO & Wt\% LiO2 & Wt $\% \quad$ B2O3 & Wt\% Na2O & Wt $\% \quad$ SiO2 \\
\hline Wt\% & MgO & 1.0000 & 0.2528 & -0.1406 & 0.2247 & -0.4277 \\
\hline Wt\% & LiO2 & 0.2528 & 1.0000 & -0.0625 & 0.5221 & -0.7308 \\
\hline Wt \% & B203 & -0.1406 & -0.0625 & 1.0000 & -0.0453 & -0.3994 \\
\hline Wt\% & $\mathrm{Na2O}$ & 0.2247 & 0.5221 & -0.0453 & 1.0000 & -0.7373 \\
\hline $\mathbf{W t} \%$ & SiO2 & -0.4277 & -0.7308 & -0.3994 & -0.7373 & 1.0000 \\
\hline
\end{tabular}

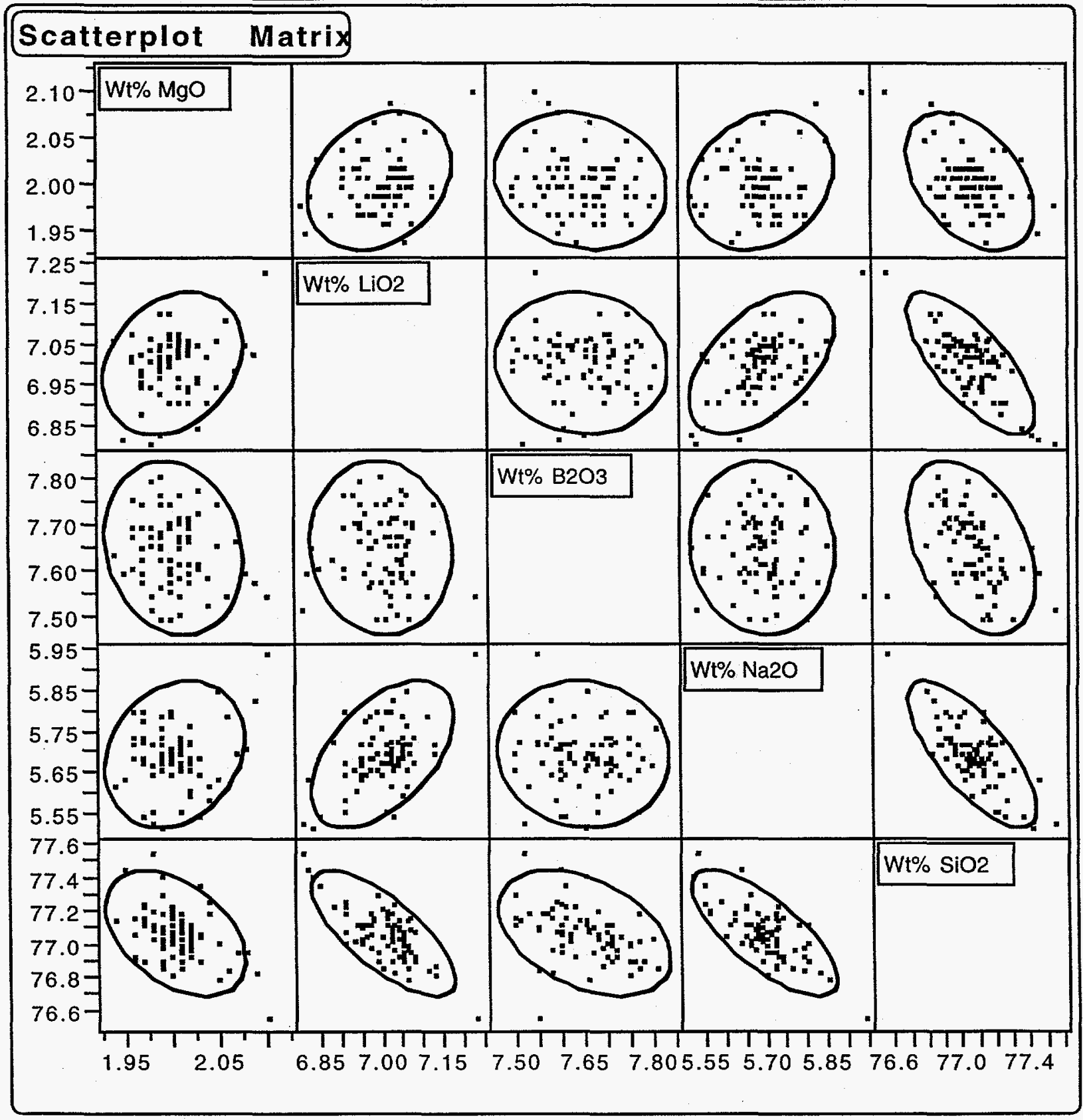

